Portland State University

PDXScholar

6-2004

\title{
Sediment Nutrient Accumulation and Nutrient Availability in Two Tidal Freshwater Marshes Along the Mattaponi River, Virginia, USA
}

Jennifer L. Morse

Portland State University, jlmorse@pdx.edu

J. Patrick Megonigal

Smithsonian Environmental Research Center

Mark R. Walbridge

West Virginia University

Follow this and additional works at: https://pdxscholar.library.pdx.edu/esm_fac

Part of the Environmental Monitoring Commons, and the Water Resource Management Commons Let us know how access to this document benefits you.

\section{Citation Details}

Morse, J. L., Megonigal, J. P., \& Walbridge, M. R. (2004). Sediment nutrient accumulation and nutrient availability in two tidal freshwater marshes along the Mattaponi River, Virginia, USA. Biogeochemistry [Dordrecht], 69(2), 175-206.

This Article is brought to you for free and open access. It has been accepted for inclusion in Environmental Science and Management Faculty Publications and Presentations by an authorized administrator of PDXScholar. Please contact us if we can make this document more accessible: pdxscholar@pdx.edu. 


\title{
Sediment nutrient accumulation and nutrient availability in two tidal freshwater marshes along the Mattaponi River, Virginia, USA
}

\author{
JENNIFER L. MORSE ${ }^{1,2, *}$, J. PATRICK MEGONIGAL ${ }^{3}$ \\ and MARK R. WALBRIDGE ${ }^{4}$ \\ ${ }^{1}$ Environmental Science and Policy Department, George Mason University, 4400 University Drive, \\ Fairfax, VA 22030, USA ${ }^{2}$ Current address: Department of Entomology, University of Maryland, 4176 \\ Plant Sciences Bldg, College Park, MD 20742, USA; ${ }^{3}$ Smithsonian Environmental Research Center, PO \\ Box 28, 647 Contees Wharf Rd, Edgewater, MD 21037, USA; ${ }^{4}$ Department of Biology, PO Box 6057, \\ West Virginia University, Morgantown, WV 26506-6057, USA; *Author for correspondence (e-mail: \\ jlmorse@umd.edu; phone: +1-301-405-3799; fax: +1-301-314-9290)
}

Received 13 December 2002; accepted in revised form 12 August 2003

Key words: Nitrogen, Nutrient limitation, Phosphorus, Sediment, Tidal freshwater marsh

\begin{abstract}
Sediment deposition is the main mechanism of nutrient delivery to tidal freshwater marshes (TFMs). We quantified sediment nutrient accumulation in TFMs upstream and downstream of a proposed water withdrawal project on the Mattaponi River, Virginia. Our goal was to assess nutrient availability by comparing relative rates of carbon $(\mathrm{C})$, nitrogen $(\mathrm{N})$, and phosphorus $(\mathrm{P})$ accumulated in sediments with the $\mathrm{C}, \mathrm{N}$, and $\mathrm{P}$ stoichiometries of surface soils and above ground plant tissues. Surface soil nutrient contents $(0.60-0.92 \% \mathrm{~N}$ and $0.09-0.13 \% \mathrm{P})$ were low but within reported ranges for TFMs in the eastern US. In both marshes, soil nutrient pools and $\mathrm{C}, \mathrm{N}$, and $\mathrm{P}$ stoichiometries were closely associated with sedimentation patterns. Differences between marshes were more striking than spatial variations within marshes: both $\mathrm{C}, \mathrm{N}$, and $\mathrm{P}$ accumulation during summer, and annual $\mathrm{P}$ accumulation rates $(0.16$ and $0.04 \mathrm{~g} \mathrm{P} \mathrm{m}^{-2}$ year $^{-1}$, respectively) in sediments were significantly higher at the downstream than at the upstream marsh. Nitrogen:P ratios $<14$ in above ground biomass, surface soils, and sediments suggest that $\mathrm{N}$ limits primary production in these marshes, but experimental additions of $\mathrm{N}$ and/or $\mathrm{P}$ did not significantly increase above ground productivity in either marsh. Lower soil N:P ratios are consistent with higher rates of sediment $\mathrm{P}$ accumulation at the downstream site, perhaps due to its greater proximity to the estuarine turbidity maximum.
\end{abstract}

\section{Introduction}

Because they play important roles in nutrient retention and transformation (Richardson 1989; Walbridge and Struthers 1993; Reddy et al. 1999), riverine marshes influence downstream water quality (Whigham et al. 1988; Correll et al. 1992). Tidal freshwater marshes (TFMs) also affect the quantity and form of nutrients reaching the sea (Simpson et al. 1983; Wolaver et al. 1983). Sedimentation, associated with tidal flooding, is an important source of both nitrogen (N) and phosphorus $(\mathrm{P})$ to TFMs-with $\mathrm{N}$ linked mainly to organic matter $(\mathrm{OM})$ and $\mathrm{P}$ primarily associated with fine-grained clay minerals (Hatton et al. 1982; Bowden 1987; Odum 1988). The nutrient status of TFMs, particularly in less impacted sites, 
is not as well documented as that of other coastal wetlands (Mitsch and Gosselink 2000).

Sediment deposition plays a critical role in the persistence of TFMs on the landscape (Stevenson et al. 1985; Cahoon et al. 1995). TFMs generally result from historical sedimentation patterns within estuaries (Orson et al. 1992; Khan and Brush 1994). Local hydrological factors (e.g., velocity and duration of flooding) as well as local geomorphology can influence spatial patterns of sediment deposition and hence nutrient availability in TFMs (Hatton et al. 1983; Puckett et al. 1993; Khan and Brush 1994; McManus 1998; Darke and Megonigal 2003). Seasonal variations in estuarine processes that affect nutrient fluxes may also be important, particularly to the marsh vegetation (Barko et al. 1991). Sedimentation in tidal marshes is generally highest during summer when low river discharge reduces erosion, storms are weaker, and vegetation traps sediment on the marsh surface (Serodes and Troude 1984; Leonard 1997; Pasternack and Brush 1998; Darke and Megonigal 2003). High rates of local deposition (particularly of fine clays) also occur near the estuarine turbidity maximum (ETM)-the upstream end of saltwater intrusion-which migrates upstream during summer as freshwater discharge decreases (Brush 1984; Dyer 1994; Lin and Kuo 2001).

Excess nutrient supplies from increased sedimentation due to changes in land use and land cover, and from atmospheric deposition, agricultural fertilizer runoff, and other anthropogenic sources, can have adverse effects on wetland ecosystems (Morris 1991; Vitousek et al. 1997). Responses may include changes in carbon (C) storage and nutrient retention (Peterjohn and Correll 1984; Morris and Bradley 1999), and shifts in plant community composition (Moore et al. 1989; Morris 1991; Verhoeven et al. 1996). These responses are likely to depend on the magnitude and characteristics of the inputs and the nature of ecosystem nutrient limitation (Schlesinger 1997; Vitousek et al. 1997).

As determined by plant growth response to specific nutrient additions, productivity in terrestrial and wetland ecosystems is generally limited by the availability of $\mathrm{N}, \mathrm{P}$, or some combination of $\mathrm{N}$ and either $\mathrm{P}$ or potassium (K) (Chapin et al. 1986; DiTommaso and Aarsen 1989). Saline, brackish, and TFMs are all generally considered to be N-limited (Valiela et al. 1973; Patrick and DeLaune 1976; Bowden 1984; Kiehl et al. 1997; Bedford et al. 1999), but there is some evidence to suggest that at least some South Carolina TFMs may be P-limited (Paludan and Morris 1999; Sundareshwar and Morris 1999). Different tropic groups also may be limited by different nutrients; in some salt marshes, vegetation is $\mathrm{N}$ limited, and the bacterial community is limited by P (Sundareshwar et al. 2003).

The widely documented difficulties associated with fertilization experiments have prompted some to seek other ways of assessing ecosystem nutrient limitation (e.g., Shaver and Melillo 1984; Chambers and Fourqurean 1991). Koerselman and Meuleman (1994) found that the N:P stoichiometry of above ground plant tissues was a reliable proxy for assessing community nutrient limitation in European wetlands; wetlands with $\mathrm{N}: \mathrm{P}$ ratios $<14$ were $\mathrm{N}$-limited, wetlands with $\mathrm{N}: \mathrm{P}$ ratios $>16$ were P-limited, and wetlands with N:P ratios between 14 and 16 were colimited by $\mathrm{N}$ and some other element ( $\mathrm{P}$ or $\mathrm{K})$. These critical $\mathrm{N}: \mathrm{P}$ ratios have 
subsequently been evaluated and successfully applied as indicators of nutrient limitation in freshwater wetlands (e.g., Güsewell et al. 1998; Bedford et al. 1999; Daoust and Childers 1999; Svengsouk and Mitsch 2001; but see Güsewell et al. 2003). Despite their utility, relationships between these critical N:P ratios and ecosystem nutrient limitation still require verification through in situ fertilization (Chapin et al. 1986; Kiehl et al. 1997; van Wijnen and Bakker 1999).

The Mattaponi River in eastern Virginia (VA) had been under consideration for a water withdrawal project to create a reservoir for the city of Newport News; litigation over the project's construction permit is ongoing as of 2003. Our study was part of a broader effort to assess 'pre-disturbance' sediment dynamics and nutrient accumulation in depositionally active areas in two TFMs along the Mattaponi River, one upstream and one downstream of the proposed water withdrawal [see Darke and Megonigal (2003) for a detailed analysis of sediment dynamics]. Specific objectives of the present study were to: (1) quantify sediment $\mathrm{C}, \mathrm{N}$, and $\mathrm{P}$ accumulation rates in these two marshes; (2) compare these rates with the $\mathrm{C}, \mathrm{N}$, and $\mathrm{P}$ contents of surface soils and above ground plant tissues; and (3) determine whether $\mathrm{N}$ and/or $\mathrm{P}$ additions increase above ground productivity. Seasonal and spatial variations in $\mathrm{C}, \mathrm{N}$, and $\mathrm{P}$ accumulation, nutrient availability, and soil $\mathrm{P}$ fractions were also determined. We hypothesized that: (1) soil nutrient availability and the C:N:P stoichiometries of surface soils and above ground plant tissues would reflect the rates and C:N:P stoichiometries of accumulated sediments; (2) sites would be N- rather than P-limited; and (3) spatial and seasonal variations in sediment deposition and nutrient availability within marshes would be more significant than differences between marshes.

\section{Site description}

Study sites were two TFMs along the western bank of the Mattaponi River, VA, one of Chesapeake Bay's most pristine tributaries (Sprague et al. 2000). Walkerton Marsh $\left(0.42 \mathrm{~km}^{2} ; 37^{\circ} 43^{\prime} \mathrm{N}, 77^{\circ} 00^{\prime} \mathrm{W}\right)$ lies $19 \mathrm{~km}$ upstream of Upper Gleason Marsh $\left(0.96 \mathrm{~km}^{2} ; 37^{\circ} 39^{\prime} \mathrm{N}, 76^{\circ} 53^{\prime} \mathrm{W}\right.$; Figure 1). The Mattaponi originates in the VA Piedmont and flows southeast, with the majority of its course in the Coastal Plain. Its confluence with the Pamunkey River forms the York River. The Mattaponi Basin covers $2363 \mathrm{~km}^{2}, 38 \%$ of the York River Basin. Land use in the Mattaponi watershed is predominantly forest (68\%) and agriculture (21\%); wetlands represent $6 \%$ of the total land area (Chesapeake Bay Program 2001).

The Mattaponi is tidal freshwater from approximately $20 \mathrm{~km}$ upstream of its mouth to the fall line near Beulahville, approximately $50 \mathrm{~km}$ further upstream. Mean river discharge near Beulahville is $6.0 \mathrm{~m}^{3} \mathrm{~s}^{-1}$, with monthly mean discharge reaching a maximum of $22.4 \mathrm{~m}^{3} \mathrm{~s}^{-1}$ in March, and a minimum of $0.6 \mathrm{~m}^{3} \mathrm{~s}^{-1}$ in August (US Geological Survey 2002). The tidal regime is microtidal, with a mean tidal range of 1.0-1.2 m (National Oceanic and Atmospheric Administration 1997). Tides are semi-diurnal with strong diurnal inequality; wind and storm events have important effects on the timing and depth of flooding. 

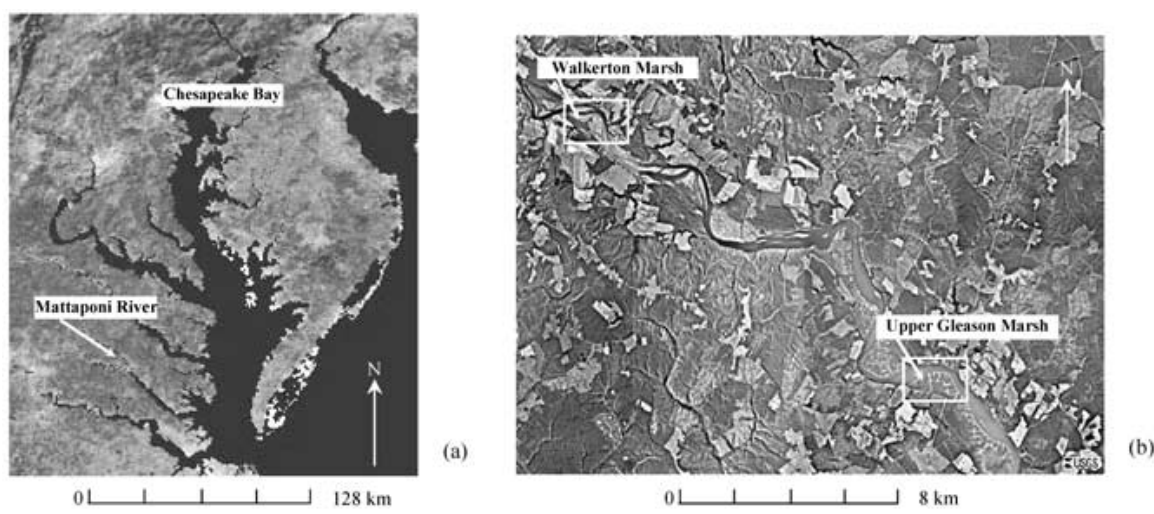

Figure 1. Geographic location of study sites, with lower Mattaponi River shown above left (a). Walkerton Marsh is $19 \mathrm{~km}$ upstream from Upper Gleason Marsh (b). Maps available through http:// mapping.usgs.gov.

Walkerton soils are predominantly mucky silty clay loams of the Lanexa and Mattan series (Terric Medisaprists); Upper Gleason soils are mostly Mattan series, with silty clay loams of the Bohicket series (Typic Sulfaquent) along river margins and tidal creeks (Three Rivers Soil and Water Conservation District, personal communication). Both marshes are palustrine emergent, with smaller areas of palustrine forest and scrub-shrub (Cowardin et al. 1979; National Wetlands Inventory 2001). The vegetation is typical of mid-Atlantic TFMs, with elevation-based mosaic patterns rather than distinct low and high marsh zones (Odum et al. 1984; Perry and Atkinson 1997). Floating-leaved plants such as Nuphar advena occur in mudflats; Pontedaria cordata L. and Peltandra virginica are found in low marsh areas. Other plant species include Acorus calamus L., Polygonum sagittatum L., Leersia oryzoides (L.) Sw, Bidens spp., Scirpus spp., Carex spp., and Typha spp. Spartina cynosuroides, a brackish water species, was found only at the downstream marsh. Nomenclature follows Godfrey and Wooten $(1979,1981)$.

\section{Methods}

\section{Sampling design}

For simplicity, the two sites will be referred to as upstream (Walkerton Marsh) and downstream (Upper Gleason Marsh), without implying a specific upstream versus downstream 'treatment.' Transects ( $80 \mathrm{~m}$ long; $n=5$ per marsh) were randomly established perpendicular to the wetland-upland border. Boardwalks allowed access to interior marsh locations while minimizing disturbance. Permanent sampling points were randomly located along each transect $(n=12$ per transect). Each sampling point was assigned to one of four location classes - mud flat (MF), river 
margin (RM; $\leq 2 \mathrm{~m}$ from the edge of the vegetated mud flat), creek margin (CM; $\leq 2 \mathrm{~m}$ from a tidal creek), and interior marsh [IM; classification scheme adapted from Leonard (1997) and Pasternack and Brush (1998)], for a total of $8 \mathrm{MF}$ (13\%), $4 \mathrm{RM}(7 \%), 9 \mathrm{CM}$ (16\%), and 37 (64\%) IM points, and $10 \mathrm{MF}$ (17\%), $5 \mathrm{RM}(8 \%)$, $10 \mathrm{CM}(17 \%)$, and $35 \mathrm{IM}(58 \%)$ points, at the upstream and downstream marshes, respectively. The proportion of sampling points in each location class is taken to represent the actual distribution of habitat types in the depositionally active zones of the marsh that we sampled. We surveyed all sample points (except at transect 1 at the upstream marsh where tree cover was too dense) using a Trimble 4700 Global Positioning System (elevations $\pm 1 \mathrm{~cm}$ ).

\section{Sediment accumulation}

Sediments were collected monthly beginning in March 1999 through February 2000 , using ceramic tiles $(15 \mathrm{~cm} \times 15 \mathrm{~cm})$ placed flush with the marsh surface at each point (Pasternack and Brush 1998; Darke and Megonigal 2003). When necessary, wire supports were placed under tiles to prevent them from sinking. The tiles were deployed and collected at low tide, along with vegetation or debris directly in contact with the tile surface. The edges and undersides of the tiles were wiped clean, and debris was trimmed along the edges before tiles were placed in sealable plastic bags. Clean tiles were placed in the same locations to collect sediment during the following month. Samples were kept on ice in the field and refrigerated immediately upon returning to the lab. Tiles that were under water at the time of sample collection, overturned, or visibly disturbed, were excluded.

Sediments were removed from tiles by brush, scraper, and deionized water from a spray bottle, passed through a 2 -mm sieve into pre-weighed, acid-washed aluminum tins, oven-dried at $105^{\circ} \mathrm{C}$ to a constant mass, and ground with a mortar and pestle. Seasonal sediment accumulation $\left(\mathrm{g} \mathrm{m}^{-2}\right)$ for each sample point was calculated by summing and composting samples by season (spring = March-May 1999; summer $=$ June-August 1999; fall $=$ September-November 1999; winter $=$ December 1999-February 2000). Because local resuspension is not quantified, these types of measurements may overestimate net sediment deposition (Callaway et al. 1996; Kastler and Wiberg 1996). Thus we use 'sediment accumulation' to refer to the process estimated by this technique.

\section{General soil characteristics}

Two replicate soil cores from a randomly selected subset of sample points $(n=3$ per location class, $n=12$ per marsh) were collected in September 1999, and analyzed for soil texture by the hydrometer method (Bouyoucos 1962), following OM digestion with $30 \% \mathrm{H}_{2} \mathrm{O}_{2}$ (Gee and Bauder 1986), and $\mathrm{pH}$ by electrode using a 1:2 soil:deionized water slurry. Analyses were performed on duplicate subsamples. To estimate soil bulk density, a second set of two replicate cores was collected in 
February 2000 from the same locations as above ( $n=12$ per marsh), using a polyvinylchloride cylinder sharpened at one end; we measured $<5 \%$ compaction on average. Bulk densities were estimated as dry soil per unit volume of replicate cores. Samples were kept on ice until processed in the lab.

\section{Carbon, $N$, and $P$ analyses}

For $\mathrm{C}, \mathrm{N}$, and $\mathrm{P}$ analyses, one soil core $(0-15 \mathrm{~cm}$, excluding surface litter) was collected in September 1999 from each sampling point $(n=58$ at the upstream marsh; $n=60$ at the downstream marsh), and kept on ice until processed in the lab. Soils were homogenized, dried to a constant mass at $90{ }^{\circ} \mathrm{C}$, and ground with a mortar and pestle. For plant tissue analyses, live above ground biomass was harvested during late June 1999 from two replicate $0.25 \mathrm{~m} \times 0.25 \mathrm{~m}$ quadrats, at each sampling point in the subset described above for general soil characteristics $(n=12$ per marsh). To avoid affecting the depositional environment, we intentionally selected small quadrats within the range of published biomass harvesting techniques for coastal marshes (e.g., Booth 1989; Paludan and Morris 1999; van Wijnen and Bakker 1999). Plant samples were kept cool until returning to the lab where they were oven-dried to a constant mass at $60^{\circ} \mathrm{C}$, and then ground using a Wiley Mill (screen size $=2 \mathrm{~mm}$ ) followed by a mortar and pestle.

Total $\mathrm{C}$ and $\mathrm{N}$ in dried and ground sediment, soil, and plant tissue samples were determined using a Perkin-Elmer 2400 Series II CHNS/O Analyzer. Sediment, soil, and plant tissue samples were also digested in a Technicon BD40 block digester using a sulfuric acid, potassium sulfate, and mercuric oxide procedure (Walbridge 1991). Total $P$ in digested samples was analyzed colorimetrically using a Technicon Autoanalyzer II (Bran and Luebbe Inc. 1989). Sediment C, N, and P concentrations were converted to areal accumulation rates using mass accumulation rates for each sample point by season. Soil C, N, and P concentrations were converted to pool sizes $\left(\mathrm{g} \mathrm{m}^{-2} 15 \mathrm{~cm}^{-1}\right)$ using corresponding soil bulk densities averaged by marsh and location. Plant tissue $\mathrm{C}, \mathrm{N}$, and $\mathrm{P}$ concentrations were converted to above ground pool sizes $\left(\mathrm{g} \mathrm{m}^{-2}\right)$ using corresponding biomass estimates.

\section{Phosphorus fractionation}

For $\mathrm{P}$ fractionation, an additional set of tiles ( $n=12$ per marsh) was placed in July 1999 at the subset of sampling points used above for general soil characteristics, and collected the following month. Soil cores $(0-15 \mathrm{~cm})$ were collected at these same points in September 1999, and placed in Ziploc bags under $\mathrm{N}_{2}$. The anaerobic environment was maintained until the $\mathrm{P}$ fraction associated with reductant-soluble $\mathrm{Fe}$ was extracted (Paludan and Jensen 1995).

Sediment and soil $\mathrm{P}$ fractions were characterized using a modification of the sequential fractionation procedure of Paludan and Jensen (1995), begun within $24 \mathrm{~h}$ of sample collection. Phosphorus fractions identified by this procedure are 
operationally defined based on the extractant. Extractions were performed at room temperature using replicate subsamples $(n=2)$ of each sediment or soil sample ( $n=12$ per marsh per sample type). Extracts were stored in Nalgene bottles at $4{ }^{\circ} \mathrm{C}$ until analysis. To maintain anoxic conditions, soil samples were processed in an $\mathrm{N}_{2}$ filled glove bag through the second extraction. Sediments were not maintained under anaerobic conditions because they were collected at low tide and were thus already exposed to air at the marsh surface.

Water-soluble $\mathrm{P}\left(\mathrm{H}_{2} \mathrm{O}-\mathrm{P}\right)$ was extracted from duplicate $0.8 \mathrm{~g}$ subsamples of each sediment and soil sample by shaking in $30 \mathrm{ml}$ deionized water for $1 \mathrm{~h}$. Samples were then centrifuged (20 min; $3400 \mathrm{rpm}$ ) and filtered (Gelman Supor $4500.45 \mu \mathrm{m}$ membrane filters). Following addition of $30 \mathrm{ml}$ deionized water, samples were shaken for an additional $2 \mathrm{~min}$, centrifuged, and filtered again. The two extracts

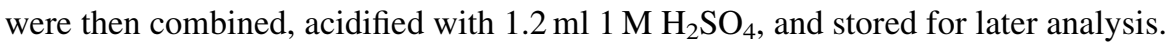

Bicarbonate dithionite (BD) was used to extract $\mathrm{P}$ adsorbed to oxidized Fe and $\mathrm{Mn}$ (Fe-P); soil pellets remaining from the previous (water-soluble P) extraction were shaken with $30 \mathrm{ml} 0.1 \mathrm{M} \mathrm{BD}$ for $1 \mathrm{~h}$, and then centrifuged and filtered as above. Soil residues were washed twice by shaking for $2 \mathrm{~min}$ with $30 \mathrm{ml}$ of BD, followed by $30 \mathrm{ml}$ of deionized water. The three extracts were then combined, acidified with $5.6 \mathrm{ml} 1 \mathrm{M} \mathrm{H}_{2} \mathrm{SO}_{4}$, and stored for later analysis. Because elemental sulfur must precipitate from the acidified solution before analysis, Fe-P was analyzed at least 2 weeks after extraction.

To estimate $\mathrm{P}$ associated with clay and $\mathrm{Al}$ oxides (Al-P), remaining soil pellets were shaken for $16 \mathrm{~h}$ with $30 \mathrm{ml} 0.1 \mathrm{M} \mathrm{NaOH}$. Following centrifugation and filtration (as above), soil pellets were washed by shaking for $2 \mathrm{~min}$ in $30 \mathrm{ml}$ of $0.1 \mathrm{M}$ $\mathrm{NaOH}$, followed by $30 \mathrm{ml}$ of deionized water. The three extracts were then combined, acidified with $1 \mathrm{M} \mathrm{H}_{2} \mathrm{SO}_{4}$ to $\mathrm{pH}$ 1, filtered with Whatman GF/F glass fiber filters to isolate $\mathrm{P}$ associated with humic acids (HA-P), and stored for later analysis. Filters were combusted in a muffle furnace at $550^{\circ} \mathrm{C}$ for $16 \mathrm{~h}$, and $\mathrm{HA}-\mathrm{P}$ was extracted with $20 \mathrm{ml} 1 \mathrm{M} \mathrm{HCl}$ in a block digester at $130{ }^{\circ} \mathrm{C}$ for $1 \mathrm{~h}$.

To extract Ca-bound $\mathrm{P}(\mathrm{Ca}-\mathrm{P})$, remaining soil pellets were shaken with $30 \mathrm{ml} 1 \mathrm{M}$ $\mathrm{HCl}$ for $1 \mathrm{~h}$, and then centrifuged and filtered as above. Soil pellets were subsequently washed with $30 \mathrm{ml}$ of deionized water, shaken for $2 \mathrm{~min}$, then centrifuged and filtered as above. Refractory organic P (Res-P) was estimated as the P remaining in each soil pellet following HCl-P extraction. Pellets were air-dried, ground with a mortar and pestle, and then oven-dried to a constant mass at $90{ }^{\circ} \mathrm{C}$. Subsamples $(0.2 \mathrm{~g})$ were combusted for $16 \mathrm{~h}$ at $550{ }^{\circ} \mathrm{C}$ in a muffle furnace, and Res$\mathrm{P}$ was extracted with $20 \mathrm{ml}$ of $1 \mathrm{M} \mathrm{HCl}$ in a block digester for $1 \mathrm{~h}$.

\section{Available and microbial biomass $P$}

Paired replicate subsamples $(n=2)$ of each sediment or soil sample were used to estimate available (Bic-P) and microbial biomass P (Mic-P; Hedley and Stewart 1982). Two sets of $0.8 \mathrm{~g}$ fresh sediment or soil subsamples were weighed into $50 \mathrm{ml}$ centrifuge tubes. Extractions were performed concurrently with the sequential $\mathrm{P}$ 
extractions described above. Available $\mathrm{P}$ was estimated by shaking sediment or soil subsamples with $30 \mathrm{ml}$ of $0.5 \mathrm{M} \mathrm{NaHCO}_{3}$ for $16 \mathrm{~h}$; samples were then centrifuged (20 min; $3400 \mathrm{rpm}$ ) and filtered (Gelman Supor $4500.45 \mu \mathrm{m}$ membrane filters). To estimate microbial biomass $\mathrm{P}, 0.5 \mathrm{ml}$ of liquid $\mathrm{CHCl}_{3}$ were added to a second set of subsamples. Centrifuge tubes were then capped, evaporated in a fume hood overnight, and then extracted with $30 \mathrm{ml}$ of $0.5 \mathrm{M} \mathrm{NaHCO}_{3}$ as described above. Supernatants were stored in Nalgene bottles at $4{ }^{\circ} \mathrm{C}$ until analysis. Microbial $\mathrm{P}$ was estimated as the increase in Bic-extractable $\mathrm{P}$ following $\mathrm{CHCl}_{3}$ fumigation, using a correction factor $\left(k_{\mathrm{p}}\right)$ of 0.4 to account for microbial $\mathrm{P}$ not converted to phosphate during $\mathrm{CHCl}_{3}$ fumigation (Hedley and Stewart 1982).

\section{Phosphorus analyses}

The inorganic $\mathrm{P}\left(\mathrm{P}_{\mathrm{i}}\right)$ concentration of each extract was determined colorimetrically as orthophosphate by the procedure of Murphy and Riley (1962), using a Technicon Autoanalyzer II (Bran and Luebbe Inc. 1989). Bicarbonate-P, $\mathrm{H}_{2} \mathrm{O}-\mathrm{P}$, Fe-P, and Al$P$ extracts were subsequently digested in an autoclave by wet oxidation, and organic $\mathrm{P}\left(\mathrm{P}_{\mathrm{o}}\right)$ concentrations in these extracts were calculated as the difference in $\mathrm{P}_{\mathrm{i}}$ concentrations of digested and non-digested extracts (Koroleff 1983). For HA-P and Res-P extracts, all $\mathrm{P}$ was considered to be $\mathrm{P}_{\mathrm{o}}$; for Ca-P extracts, all $\mathrm{P}$ was considered to be $\mathrm{P}_{\mathrm{i}}$. Total $\mathrm{P}$ was calculated by summing the $\mathrm{P}$ concentrations of all nine fractions $\left(\mathrm{H}_{2} \mathrm{O}-\mathrm{P}_{\mathrm{i}}+\mathrm{H}_{2} \mathrm{O}-\mathrm{P}_{\mathrm{o}}+\mathrm{Fe}-\mathrm{P}_{\mathrm{i}}+\mathrm{Fe}-\mathrm{P}_{\mathrm{o}}+\mathrm{Al}-\mathrm{P}_{\mathrm{i}}+\mathrm{Al}-\mathrm{P}_{\mathrm{o}}+\mathrm{Ca}-\mathrm{P}+\mathrm{HA}-\right.$ $\mathrm{P}+$ Res-P). Total $\mathrm{P}_{\mathrm{o}}$ was estimated by summing $\mathrm{P}_{\mathrm{o}}$ fractions $\left(\mathrm{H}_{2} \mathrm{O}-\mathrm{P}_{\mathrm{o}}+\mathrm{Fe}-\mathrm{P}_{\mathrm{o}}+\mathrm{Al}-\right.$ $\mathrm{P}_{\mathrm{o}}+\mathrm{HA}-\mathrm{P}+$ Res-P).

\section{In situ fertilization experiment}

An in situ fertilization experiment, following procedures used by Valiela et al. (1973), Chambers and Fourqurean (1991), Kiehl et al. (1997), and van Wijnen and Bakker (1999), was used to determine the nature of nutrient limitation at each site. In each marsh, four replicate treatment blocks were established at the beginning of the growing season (March 2000) in high marsh vegetation zones, chosen to reduce the likelihood of nutrient applications being washed away by tidal flooding, that were similar in vegetation and elevation. Each block was assigned to a fertilization treatment $(\mathrm{N}, \mathrm{P}, \mathrm{N}+\mathrm{P}$, or control). Individual treatment blocks were separated by at least $8 \mathrm{~m}$, to reduce the likelihood of fertilizer transport between blocks caused by tidal action. Within each treatment block, $1 \mathrm{~m}^{2}$ experimental subplots $(n=4)$ spaced at least $1 \mathrm{~m}$ apart were established for a total of 16 subplots per marsh. Nutrients were applied in March 2000, using Osmocote ${ }^{\mathbb{R}}$ slow-release granules to minimize nutrient loss (Worm et al. 2000). Application rates were $22.5 \mathrm{~g} \mathrm{~N} \mathrm{~m}^{-2}$, as urea $\left(39 \% \mathrm{~N}\right.$ by weight), and $11.2 \mathrm{~g} \mathrm{P} \mathrm{m}^{-2}$, as triple super phosphate $(45 \% \mathrm{P}$ by weight). 
Live above ground biomass at the peak of the growing season, an estimate of above ground net primary production (ANPP; but see Whigham et al. 1978), was harvested from one $0.25 \mathrm{~m} \times 0.25 \mathrm{~m}$ quadrat in each experimental plot. Soil cores $(0-15 \mathrm{~cm}$, excluding surface litter) were collected from each replicate plot both prior to fertilization and at the time of plant harvest, to assess soil $\mathrm{C}, \mathrm{N}$, and $\mathrm{P}$ content before and after fertilization.

\section{Statistics}

Two-way analysis of variance (ANOVA) was used to determine differences between marshes and locations within marshes; 3-way ANOVAs were used to identify significant differences between marshes, locations, and sample types (plants, soils, or sediments) or seasons. ANOVAs were performed using PROC GLM in SAS Version 8 for Windows (SAS Institute 1999). Type III sums of squares and least squared means were used when analyzing unbalanced data sets. For balanced data sets, (i.e., when the subsets of $n=12$ points per marsh were analyzed) values were weighted by factors proportional to the area represented by each habitat class (as approximated by the number of sampling points in each class), to allow appropriate comparisons of the two sites.

When main effects were significant, the Ryan-Einot-Gabriel-Welsch Multiple Range Test (for balanced data sets), or the Tukey-Kramer procedure (for unbalanced data sets), was used to identify means that were significantly different. Dunnett's test was used to compare above ground biomass in fertilized versus control plots. When significant two- and three-way interactions were found, PROC GLM was repeated separately for each marsh to examine differences between locations, seasons, or sample types.

Where interactions were significant, ANOVAs were also attempted using logtransformed variables, but because this did not remove the interactions, the original values were used. Paired $t$-tests were used to determine whether soil $\mathrm{N}$ and $\mathrm{P}$ concentrations were significantly different before and after fertilization. To examine relationships between sediment and soil nutrients in each marsh, linear regressions were performed on $\mathrm{C}, \mathrm{N}$, and $\mathrm{P}$ results using PROC REG in SAS Version 8 for Windows (SAS Institute 1999).

\section{Results}

\section{Marsh surface elevation}

Mean elevations of sample points in each location class are shown in Figure 2. Overall, the two marshes were not significantly different in elevation $(-0.05 \pm 0.04 \mathrm{~m}$ upstream vs. $0.03 \pm 0.03 \mathrm{~m}$ downstream). Elevations were significantly different by location, with IM locations significantly higher than MF locations $(p<0.0279$; Figure 2). 


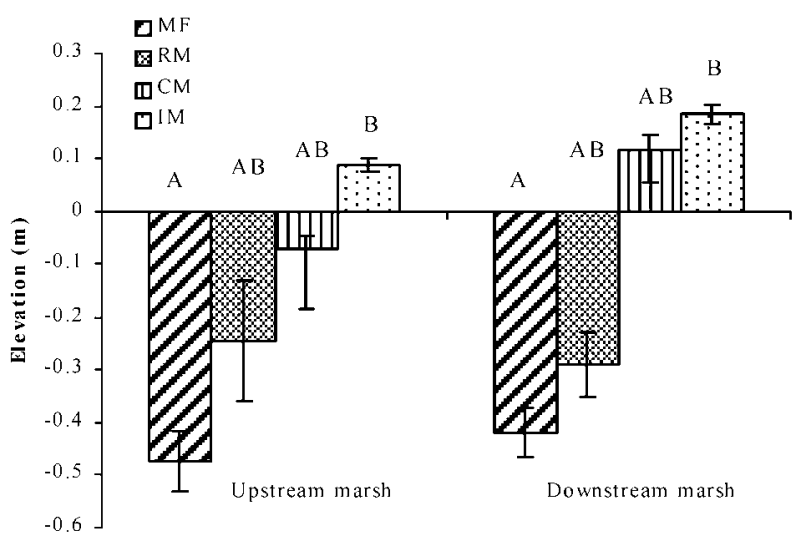

Figure 2. Sampling point elevations by location class. Bars are \pm standard errors. Marshes are significantly different at $p<0.05$ when labeled with different letter series (ABC $>\mathrm{XYZ}$ ). Locations within marshes are significantly different at $p<0.05$ when labeled with different letters.

\section{General soil characteristics}

Soils at the upstream marsh were significantly lower in $\mathrm{pH}$ and bulk density, and significantly higher in $\mathrm{C}$, than soils at the downstream marsh (Table 1). As approximated by doubling \% C (Nelson and Sommers 1996), soils at the upstream marsh were organic (28\% OM); soils at the downstream marsh were mineral (16\% $\mathrm{OM})$. Soil characteristics did not vary significantly by location in either marsh, except for \% $\mathrm{C}$ which was significantly higher in IM locations in both marshes (Table 1).

\section{Sediment mass and $C, N$, and $P$ accumulation}

Sediment accumulation was significantly higher over all seasons and locations at the downstream $\left(5.77 \mathrm{~kg} \mathrm{~m}^{-2}\right.$ year $\left.^{-1}\right)$ versus the upstream marsh $\left(1.43 \mathrm{~kg} \mathrm{~m}^{-2}\right.$ year $^{-1}$; Figure 3 ). Sediment accumulation decreased with increasing distance from the river, and was significantly lower in IM than in MF locations at each marsh. Significant differences in seasonal accumulation rates occurred only at the downstream marsh, where sediment accumulation was highest in summer, followed by spring, fall, and then winter (Figure 3).

Similar to trends observed for sediment mass, sediment $\mathrm{C}, \mathrm{N}$, and $\mathrm{P}$ accumulation rates were: (1) significantly higher at the downstream marsh; (2) significantly lower in IM than in MF locations in each marsh; and (3) exhibited similar spatial distributions by location (Table 2). At both sites, $\mathrm{P}$ accumulation rates were higher in summer than in other seasons. Sediment $\mathrm{C}$ and $\mathrm{N}$ accumulations were also significantly higher in summer at the downstream marsh. Accumulated sediments at 
Table 1. General soil characteristics. Values are weighted means \pm standard errors, except for $\mathrm{pH}$, where ranges are presented in parentheses. Marshes are significantly different at $p<0.05$ when labeled with different latter series (ABC $>$ XYZ). Locations within marshes are significantly different at $p<0.05$ when labeled with different letters. Soil $\mathrm{pH}$, bulk density, \% OM, and P pool sizes are significantly different between marshes $(p<0.05) ; \%$ sand, $\%$ silt, \% clay, and C and $\mathrm{N}$ pool sizes are not significantly different between marshes. Differences between locations are significant at $p<0.05$ for $\%$ OM only, where IM locations in both marshes are significantly higher than other locations.

\begin{tabular}{|c|c|c|c|c|c|c|c|c|c|c|c|}
\hline \multirow[t]{2}{*}{ Location } & \multirow[t]{2}{*}{$n$} & \multirow[t]{2}{*}{$\mathrm{pH}$} & \multirow{2}{*}{$\begin{array}{l}\text { Bulk density } \\
\left(\mathrm{g} \cdot \mathrm{cm}^{3}\right)\end{array}$} & \multicolumn{3}{|c|}{ Soil Texture (\%) } & \multirow[t]{2}{*}{$n$} & \multirow{2}{*}{$\begin{array}{l}\text { Organic } \\
\text { matter }^{*}(\%)\end{array}$} & \multirow{2}{*}{$\begin{array}{l}\text { Carbon } \\
\left(\mathrm{g} \cdot \mathrm{m}^{-2}\right)\end{array}$} & \multirow{2}{*}{$\begin{array}{l}\text { Nitrogen } \\
\left(\mathrm{g} \cdot \mathrm{m}^{-2}\right)\end{array}$} & \multirow{2}{*}{$\begin{array}{l}\text { Phosphorus } \\
\left(\mathrm{g} \cdot \mathrm{m}^{-2}\right)\end{array}$} \\
\hline & & & & Sand & Silt & Clay & & & & & \\
\hline$h$ & 12 & $2)^{x}$ & $0.1 / \pm$ & $7 \pm 3.5^{\mathrm{A}}$ & $48.0 \pm 12.5^{\mathrm{A}}$ & $0.1^{\mathrm{x}}$ & 58 & 27.8 & $8.6^{\mathrm{A}}$ & $8.7^{\mathrm{A}}$ & $2^{x}$ \\
\hline Tudflat (MF) & 3 & 6.16 & $0.30 \pm 0.01^{\mathrm{x}}$ & $18.0 \pm 8.0^{\mathrm{A}}$ & $22.8 \pm 3.3^{\mathrm{A}}$ & $59.3 \pm 9.7^{\mathrm{x}}$ & 8 & 14.82 & $3368.1 \pm 225.6^{\mathrm{A}}$ & $237.9 \pm 15.9^{\mathrm{A}}$ & $26.4 \pm 4.0^{7}$ \\
\hline River Margin (RM) & 3 & $5.85(5.45-6.19)^{\mathrm{x}}$ & $0.27 \pm 0.11^{\mathrm{X}}$ & $7.4 \pm 0.9^{\mathrm{A}}$ & $39.8 \pm 18.6^{\mathrm{A}}$ & $52.9 \pm 19.5^{\mathrm{X}}$ & & $18.68 \pm 4.60^{\mathrm{B}}$ & $3929.2 \pm 968.6^{\mathrm{A}}$ & $262.0 \pm 64.1^{\mathrm{A}}$ & $24.2 \pm 4.9^{X}$ \\
\hline Creek Marg & & $5.79(5.38-6.07)^{\mathrm{x}}$ & $0.22 \pm 0.04^{\mathrm{X}}$ & $0.8 \pm 0.2^{\mathrm{A}}$ & $56.3 \pm 13.3^{\mathrm{A}}$ & $42.9 \pm 13.2^{\mathrm{X}}$ & 9 & $26.12 \pm 3.20^{\mathrm{B}}$ & $3939.6 \pm 523.8^{\mathrm{A}}$ & $29.9^{\mathrm{A}}$ & 33.5 \\
\hline Interior Marsh (IM) & 3 & $6.01(5.40-6.27)^{\mathrm{x}}$ & $0.13 \pm 0.02^{\mathrm{X}}$ & $4.1 \pm 2.6^{\mathrm{A}}$ & $52.3 \pm 10.6^{\mathrm{A}}$ & $43.6 \pm 8.0^{\mathrm{x}}$ & 37 & $32.54 \pm 1.08^{\mathrm{A}}$ & $3078.5 \pm 101.6^{\mathrm{A}}$ & $199.5 \pm 7.1^{\mathrm{A}}$ & $17.8 \pm 0.8^{X}$ \\
\hline own & 12 & )$^{\mathrm{A}}$ & 0 & $9^{\mathrm{A}}$ & $1^{\mathrm{A}}$ & $6.8^{\mathrm{A}}$ & 60 & $76^{x}$ & $2^{\mathrm{A}}$ & $1.3^{\mathrm{A}}$ & $2.6^{A}$ \\
\hline Mudflat (MF) & 3 & $6.52(6.28-6.66)^{\mathrm{A}}$ & $0.32 \pm 0.02^{\mathrm{A}}$ & $1.9 \pm 1.5^{\mathrm{A}}$ & $20.2 \pm 2.3^{\mathrm{A}}$ & $78.0 \pm 3.3^{\mathrm{A}}$ & 10 & $10.96 \pm 0.30^{\mathrm{Y}}$ & $2626.1 \pm 69.9^{\mathrm{A}}$ & $207.6 \pm 5.2^{\mathrm{A}}$ & $62.5 \pm 3.1^{A}$ \\
\hline River Margin (RM) & 3 & $6.78(6.62-6.95)^{\mathrm{A}}$ & $0.32 \pm 0.05^{\mathrm{A}}$ & $0.8 \pm 0.5^{\mathrm{A}}$ & $22.8 \pm 5.7^{\mathrm{A}}$ & $73.5 \pm 5.7^{\mathrm{A}}$ & 5 & $12.98 \pm 1.10^{\mathrm{Y}}$ & $3068.8 \pm 264.3^{\mathrm{A}}$ & $240.0 \pm 18.0^{\mathrm{A}}$ & $62.8 \pm 4.7^{A}$ \\
\hline Creek Margin (CM) & 3 & $6.66(6.24-7.01)^{\mathrm{A}}$ & $0.38 \pm 0.03^{\mathrm{A}}$ & $2.1 \pm 0.9^{\mathrm{A}}$ & $25.8 \pm 4.4^{\mathrm{A}}$ & $75.0 \pm 3.7^{\mathrm{A}}$ & 10 & $12.00 \pm 0.38^{\mathrm{Y}}$ & $3464.5 \pm 1100.0^{\mathrm{A}}$ & $284.2 \pm 5.7^{\mathrm{A}}$ & $69.5 \pm 4.8$ \\
\hline Interior Marsh (IM) & 3 & $6.49(6.41-6.53)^{\mathrm{A}}$ & $0.33 \pm 0.02^{\mathrm{A}}$ & $3.7 \pm 2.9^{\mathrm{A}}$ & $45.1 \pm 13.9^{\mathrm{A}}$ & $51.2 \pm 16.6^{\mathrm{A}}$ & 35 & $18.54 \pm 1.06^{\mathrm{X}}$ & $4642.0 \pm 264.5^{\mathrm{A}}$ & $344.6 \pm 15.0^{\mathrm{A}}$ & $61.7 \pm 4.0^{A}$ \\
\hline
\end{tabular}

*Total $\mathrm{C}$ was assumed to be exclusively organic $\mathrm{C}$ in these non-calcareous soils. 


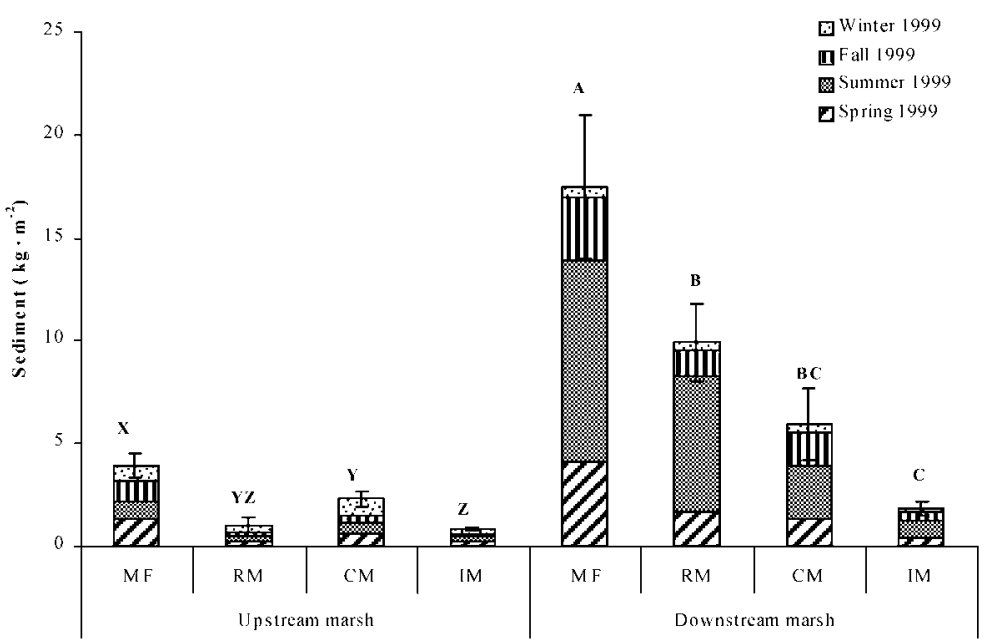

Figure 3. Sediment deposition by marsh and location, with seasons stacked. Bars are \pm standard errors over all seasons. Marshes are significantly different at $p<0.05$ when labeled with different letter series $(\mathrm{ABC}<\mathrm{XYZ})$. Locations within marshes are significantly different at $p<0.05$ when labeled with different letters. Summer was significantly higher than other seasons only at the downstream marsh $(p<0.05)$.

the upstream marsh had significantly higher \% OM than at the downstream marsh (22.9 and $12.7 \%$, respectively).

Carbon, $N$, and $P$ in surface soils and above ground plant tissues

We report pool sizes $\left(\mathrm{g} \mathrm{m}^{-2}\right)$ to reflect the availability of $\mathrm{C}, \mathrm{N}$, and $\mathrm{P}$ to plants in surface soils $(0-15 \mathrm{~cm})$. To facilitate comparisons with other published values, we summarize here our $\mathrm{C}, \mathrm{N}$, and $\mathrm{P}$ concentrations though we primarily report nutrients in $\mathrm{g} \mathrm{m}^{-2}$. Soils in the upstream marsh ranged from 6.0 to $23.4 \% \mathrm{C}$, in $\mathrm{MF}$ and $\mathrm{CM}$ locations; from 0.36 to $1.54 \% \mathrm{~N}$ in $\mathrm{MF}$ and $\mathrm{CM}$ locations; and 0.025 to $0.152 \% \mathrm{P}$ in IM and CM locations, respectively. Soils in the downstream marsh ranged from 4.9 to $17.1 \% \mathrm{C}$ and from 0.37 to $1.14 \% \mathrm{~N}$ in $\mathrm{MF}$ and $\mathrm{CM}$ locations, respectively; and from 0.070 to $0.17 \%$ P, both in CM locations (Morse 2002).

Only total $\mathrm{P}$ in surface $(0-15 \mathrm{~cm})$ soils differed significantly between marshes, with pool sizes about twice as large at the downstream $\left(64.1 \mathrm{~g} \mathrm{P} \mathrm{m}^{-2}\right)$ versus the upstream marsh $\left(25.5 \mathrm{~g} \mathrm{P} \mathrm{m}^{-2}\right.$; Table 1). Spatial patterns were less apparent than for sediment $\mathrm{C}, \mathrm{N}$, and $\mathrm{P}$ accumulation rates. At the upstream marsh, surface soil $\mathrm{C}, \mathrm{N}$, and $\mathrm{P}$ pool sizes were all significantly lower in IM than in CM locations (Table 1). At the downstream marsh, $\mathrm{C}$ and $\mathrm{N}$ pool sizes in surface soils were significantly higher in IM than in MF locations, and generally increased with increasing distance from the river (Table 1). 
Table 2. Carbon, nitrogen and phosphorus in accumulated sediments, by marsh, location, and season. Sample size $(n)$ is the same for C, N, and P analyses. Values are weighted means \pm standard errors. Marshes are significantly different at $p<0.05$ when labeled with different letters. Differences between marshes are significant a $p<0.05$ for total accumulation of $\mathrm{C}, \mathrm{N}$, and $\mathrm{P}$; over all seasons, MF locations were significantly higher than IM locations in both marshes. Significant differences between seasons, over all locations within each marsh, are indicated in italics. Summer accumulation of C,N, and P was significantly higher than other seasons at the downstream marsh, but only summer P accumulation was higher than other seasons at the upstream marsh.

\begin{tabular}{|c|c|c|c|c|c|c|c|c|c|c|c|c|c|c|c|c|}
\hline \multirow[t]{2}{*}{ Location } & \multirow[t]{2}{*}{$n^{*}$} & \multicolumn{5}{|c|}{ Carbon $\left(\mathrm{g} \cdot \mathrm{m}^{-2}\right)$} & \multicolumn{5}{|c|}{ Nitrogen $\left(\mathrm{g} \cdot \mathrm{m}^{-2}\right)$} & \multicolumn{5}{|c|}{ Phosphorus $\left(\mathrm{g} \cdot \mathrm{m}^{-2}\right)$} \\
\hline & & $\begin{array}{l}\text { Spring } \\
1999\end{array}$ & $\begin{array}{l}\text { Summer } \\
1999\end{array}$ & & $\begin{array}{l}\text { Winter } \\
1999\end{array}$ & $\begin{array}{l}\text { Annual } \\
\text { Mean }\end{array}$ & $\begin{array}{l}\text { Spring } \\
1999\end{array}$ & $\begin{array}{l}\text { Summer } \\
1999\end{array}$ & $\begin{array}{l}\text { Fall } \\
1999\end{array}$ & $\begin{array}{l}\text { Winter } \\
1999\end{array}$ & nual & $\begin{array}{l}\text { Spring } \\
1999\end{array}$ & $\begin{array}{l}\text { Summer } \\
1999\end{array}$ & $\begin{array}{l}\text { Fall } \\
1999\end{array}$ & $\begin{array}{l}\text { Winter } \\
1999\end{array}$ & $\begin{array}{l}\text { Annual } \\
\text { Mean }\end{array}$ \\
\hline strear & 58 & $38.8 \pm 9.9$ & $37.4 \pm 4.5$ & $32.8 \pm 5.8$ & $39.8 \pm 5.4$ & $37.2 \pm 3.3^{x}$ & $1 \pm 0.6$ & $3.0 \pm 0.3$ & $2.6 \pm 0.4$ & $3.4 \pm 0.5$ & $3.0 \pm 0.2^{\mathrm{x}}$ & $0.51 \pm 0.10$ & $0.80 \pm 0.09$ & $0.40 \pm 0.06$ & $0.55 \pm 0.09$ & $0.57 \pm 0.04^{x}$ \\
\hline IF & 8 & $159.8 \pm 119.2$ & $74.2 \pm 19.9$ & $111.2 \pm 22.5$ & $66.4 \pm 15.5$ & $94.8 \pm 18.7^{\mathrm{X}}$ & $10.2 \pm 7.1$ & $5.3 \pm 1.4$ & $8.2 \pm 1.6$ & $5.0 \pm 1.3$ & $6.7 \pm 1.2^{\mathrm{x}}$ & $1.5 \pm 1.0$ & $1.39 \pm 0.41$ & $1.20 \pm 0.27$ & $0.75 \pm 0.24$ & $1.17 \pm 0.20^{x}$ \\
\hline M & 4 & $23.2 \pm 7.9$ & $24.9 \pm 9.2$ & $14.2 \pm 5.3$ & $22.3 \pm 9.9$ & $21.2 \pm 3.8^{\mathrm{YZ}}$ & $1.7 \pm 0.5$ & $1.9 \pm 0.8$ & $1.3 \pm 0.5$ & $1.9 \pm 0.9$ & $1.7 \pm 0.3^{\mathrm{z}}$ & $0.25 \pm 0.08$ & $1.41 \pm 0.21$ & $0.20 \pm 0.09$ & $0.38 \pm 0.20$ & $0.34 \pm 0.07^{\mathrm{Y}}$ \\
\hline CM & 9 & $47.1 \pm 15.3$ & $53.0 \pm 6.5$ & $36.7 \pm 4.1$ & $77.7 \pm 17.6$ & $53.6 \pm 6.4^{\mathrm{YZ}}$ & $4.1 \pm 1.3$ & $4.5 \pm 0.6$ & $3.3 \pm 0.4$ & $6.6 \pm 1.5$ & $4.6 \pm 0.5^{\mathrm{Y}}$ & $0.92 \pm 0.27$ & $0.56 \pm 0.07$ & $0.57 \pm 0.08$ & $1.24 \pm 0.28$ & $1.03 \pm 0.12^{\mathrm{x}}$ \\
\hline $\mathbb{M}$ & 37 & $25.4 \pm 4.3$ & $27.0 \pm 4.2$ & $16.9 \pm 3.8$ & $26.7 \pm 5.1$ & $24.0 \pm 2.2^{2}$ & $2.2 \pm 0.4$ & $2.2 \pm 0.3$ & $1.4 \pm 0.3$ & $2.4 \pm 0.5$ & $2.1 \pm 0.2^{z}$ & $0.33 \pm 0.06$ & $0.80 \pm 0.09$ & $0.20 \pm 0.04$ & $0.36 \pm 0.08$ & $0.36 \pm 0.03^{Y}$ \\
\hline Downstream marsh & 60 & $64.1 \pm 18.6$ & $180.3 \pm 38.8$ & $.9 \pm 13.3$ & $16.2 \pm 3.0$ & $82.5 \pm 12.0^{\mathrm{A}}$ & $5.8 \pm 1.6$ & $15.4 \pm 3.1$ & $6.3 \pm 1.3$ & $1.4 \pm 0.3$ & $7.3 \pm 1.0^{\mathrm{A}}$ & $1.50 \pm 0.49$ & $5.66 \pm 1.35$ & $1.60 \pm 0.35$ & $0.35 \pm 0.06$ & $2.28 \pm 0.39^{\wedge}$ \\
\hline MF & 10 & $224.6 \pm 119.1$ & $561.8 \pm 169.9$ & $171.3 \pm 57.8$ & $31.9 \pm 14.0$ & $249.2 \pm 61.4^{\wedge}$ & $20.2 \pm 10.6$ & $45.9 \pm 13.2$ & $16.2 \pm 5.5$ & $2.8 \pm 1.2$ & $21.4 \pm 5.0^{\wedge}$ & $5.57 \pm 3.33$ & $19.32 \pm 5.72$ & $4.23 \pm 1.56$ & $0.70 \pm 0.28$ & $7.61 \pm 2.06^{\wedge}$ \\
\hline M & 6 & $88.8 \pm 25.9$ & $360.0 \pm 90.9$ & $72.7 \pm 33.1$ & $23.2 \pm 6.6$ & $140.5 \pm 38.9^{\mathrm{B}}$ & $8.1 \pm 2.4$ & $32 \pm 8.3$ & $6.8 \pm 3.1$ & $2 \pm 0.6$ & $12.6 \pm 3.5^{\mathrm{B}}$ & $2.10 \pm 0.70$ & $11.39 \pm 3.94$ & $1.77 \pm 0.91$ & $0.54 \pm 0.15$ & $4.12 \pm 1.43^{\mathrm{B}}$ \\
\hline cM & 10 & $81.6 \pm$ & 2.5 & \pm 30.6 & 8.2 & $81.8 \pm 17.5^{\mathrm{BC}}$ & & 12.1 & 2.9 & $2.2 \pm 0.7$ & $7.3 \pm 1.6^{\mathrm{BC}}$ & 0.94 & 0.51 & $2.21 \pm 0.85$ & $0.51 \pm 0.15$ & $1.64 \pm 0.35^{\mathrm{BC}}$ \\
\hline M & 34 & $23.0 \pm 3.5$ & $49.9 \pm 7.8$ & $31.2 \pm 7.0$ & $7.8 \pm 1.2$ & $28.0 \pm 3.0^{\mathrm{C}}$ & $2.1 \pm 0.3$ & $4.5 \pm 0.7$ & $2.9 \pm 0.7$ & $0.7 \pm 0.1$ & $2.5 \pm 0.3^{\mathrm{C}}$ & $0.51 \pm 0.09$ & $1.56 \pm 0.27$ & $0.63 \pm 0.14$ & $0.17 \pm 0.03$ & $0.72 \pm 0.09^{\mathrm{C}}$ \\
\hline
\end{tabular}

*Spring 1999 missing samples: upstream marsh (4 MF); downstream marsh (3 MF, 2 RM). Summer 1999 missing samples: downstream marsh (1 CM). 
Table 3. Above ground plant biomass, and $\mathrm{C}, \mathrm{N}$, and $\mathrm{P}$ pool sizes $\left(\mathrm{g} \cdot \mathrm{m}^{-2}\right)$ by marsh and location. Values are weighted means \pm standard errors. Marshes are significantly different at $p<0.05$ when labeled with different letter series $(\mathrm{ABC}>\mathrm{XYZ})$. Locations within marshes are significantly different at $p<0.05$ when labeled with different letters. Marshes are not significantly different $(p<0.05)$ with respect to any of the variables. Mudflat (MF) locations are significantly lower than CM and IM locations in both marshes for all variables.

\begin{tabular}{lrlccc}
\hline Location & $n$ & $\begin{array}{l}\text { Biomass } \\
\left(\mathrm{g} \cdot \mathrm{m}^{-2}\right)\end{array}$ & $\begin{array}{l}\text { Carbon } \\
\left(\mathrm{g} \cdot \mathrm{m}^{-2}\right)\end{array}$ & $\begin{array}{l}\text { Nitrogen } \\
\left(\mathrm{g} \cdot \mathrm{m}^{-2}\right)\end{array}$ & $\begin{array}{l}\text { Phosphorus } \\
\left(\mathrm{g} \cdot \mathrm{m}^{-2}\right)\end{array}$ \\
\hline Upstream marsh & 12 & $457.1 \pm 100.1^{\mathrm{A}}$ & $188.8 \pm 44.1^{\mathrm{A}}$ & $7.0 \pm 1.9^{\mathrm{A}}$ & $1.08 \pm 0.35^{\mathrm{A}}$ \\
MF & 3 & $167.6 \pm 57.0^{\mathrm{B}}$ & $70.4 \pm 23.5^{\mathrm{B}}$ & $2.7 \pm 0.8^{\mathrm{B}}$ & $0.56 \pm 0.15^{\mathrm{B}}$ \\
RM & 3 & $276.0 \pm 62.6^{\mathrm{AB}}$ & $117.4 \pm 26.3^{\mathrm{AB}}$ & $5.1 \pm 1.3^{\mathrm{AB}}$ & $1.21 \pm 0.26^{\mathrm{AB}}$ \\
CM & 3 & $508.4 \pm 134.2^{\mathrm{A}}$ & $212.4 \pm 66.0^{\mathrm{A}}$ & $10.2 \pm 2.8^{\mathrm{A}}$ & $1.27 \pm 0.31^{\mathrm{A}}$ \\
IM & 3 & $526.8 \pm 83.4^{\mathrm{A}}$ & $216.4 \pm 36.0^{\mathrm{A}}$ & $7.3 \pm 1.6^{\mathrm{A}}$ & $0.84 \pm 0.15^{\mathrm{A}}$ \\
Downstream marsh & 12 & $435.7 \pm 125.7^{\mathrm{A}}$ & $175.5 \pm 56.5^{\mathrm{A}}$ & $7.2 \pm 2.1^{\mathrm{A}}$ & $0.91 \pm 0.24^{\mathrm{A}}$ \\
MF & 3 & $181.7 \pm 62.1^{\mathrm{B}}$ & $74.5 \pm 25.7^{\mathrm{B}}$ & $4.1 \pm 1.4^{\mathrm{B}}$ & $0.78 \pm 0.06^{\mathrm{B}}$ \\
RM & 3 & $462.7 \pm 25.7^{\mathrm{AB}}$ & $188.6 \pm 11.2^{\mathrm{AB}}$ & $7.3 \pm 0.7^{\mathrm{AB}}$ & $0.80 \pm 0.01^{\mathrm{AB}}$ \\
CM & 3 & $352.8 \pm 31.3^{\mathrm{A}}$ & $142.2 \pm 10.8^{\mathrm{A}}$ & $6.6 \pm 0.6^{\mathrm{A}}$ & $1.08 \pm 0.23^{\mathrm{A}}$ \\
IM & 3 & $511.0 \pm 12.3^{\mathrm{A}}$ & $212.0 \pm 55.3^{\mathrm{A}}$ & $8.3 \pm 2.0^{\mathrm{A}}$ & $0.78 \pm 0.09^{\mathrm{A}}$ \\
\hline
\end{tabular}

Peak growing season above ground biomass (a conservative estimate of ANPP in TFMs; Whigham et al. 1978) ranged from 96.0 to $775.8 \mathrm{~g} \mathrm{~m}^{-2}$, averaging $457.1 \pm 100.1 \mathrm{~g} \mathrm{~m}^{-2}$ and $435.7 \pm 125.7 \mathrm{~g} \mathrm{~m}^{-2}$, at the upstream and downstream marshes, respectively (Table 3). Above ground NPP did not differ significantly between marshes, but was significantly lower in MF than in CM and IM locations at both marshes (Table 3). Pool sizes of $\mathrm{C}, \mathrm{N}$, and $\mathrm{P}$ in aboveground biomass ranged from 38.9 to $344.3 \mathrm{~g} \mathrm{~m}^{-2}$ for $\mathrm{C}, 1.9$ to $15.8 \mathrm{~g} \mathrm{~m}^{-2}$ for $\mathrm{N}$, and 0.21 to $1.89 \mathrm{~g} \mathrm{~m}^{-2}$ for $\mathrm{P}$ (Table 3). Pool sizes of $\mathrm{C}, \mathrm{N}$, and $\mathrm{P}$ in above ground biomass also did not differ significantly between marshes, but were significantly lower in MF than in CM and IM locations at both marshes.

$C: N: P$ stoichiometry of accumulated sediments, surface soils, and plant tissues

Sediment C:N, C:P, and N:P ratios ranged from 5.9 to $22.0,18.1$ to $204.0,1.4$ to 17.0, respectively, and were significantly higher at the upstream than at the downstream marsh (Figure 4). At the upstream marsh, sediment $\mathrm{C}: \mathrm{N}$ ratios were significantly lower in $\mathrm{CM}$ and IM than in MF and RM locations, sediment C:P ratios were significantly lower in $\mathrm{CM}$ than in other locations, and sediment $\mathrm{N}: \mathrm{P}$ ratios were significantly lower in CM than in IM locations. Carbon:P and N:P ratios were significantly lower in summer at the upstream site. No significant spatial or seasonal variations in $\mathrm{C}: \mathrm{N}, \mathrm{C}: \mathrm{P}$, or $\mathrm{N}: \mathrm{P}$ ratios were observed at the downstream site.

Carbon:N, C:P, and N:P ratios ranged from 1.9 to $22.4,33.2$ to 367.8 , and 2.4 to 21.0 , respectively in surface soils, and from 15.9 to $36.4,134.0$ to 270.5 , and 5.3 to 11.6, respectively in above ground plant tissues (Figure 5). As for accumulated 

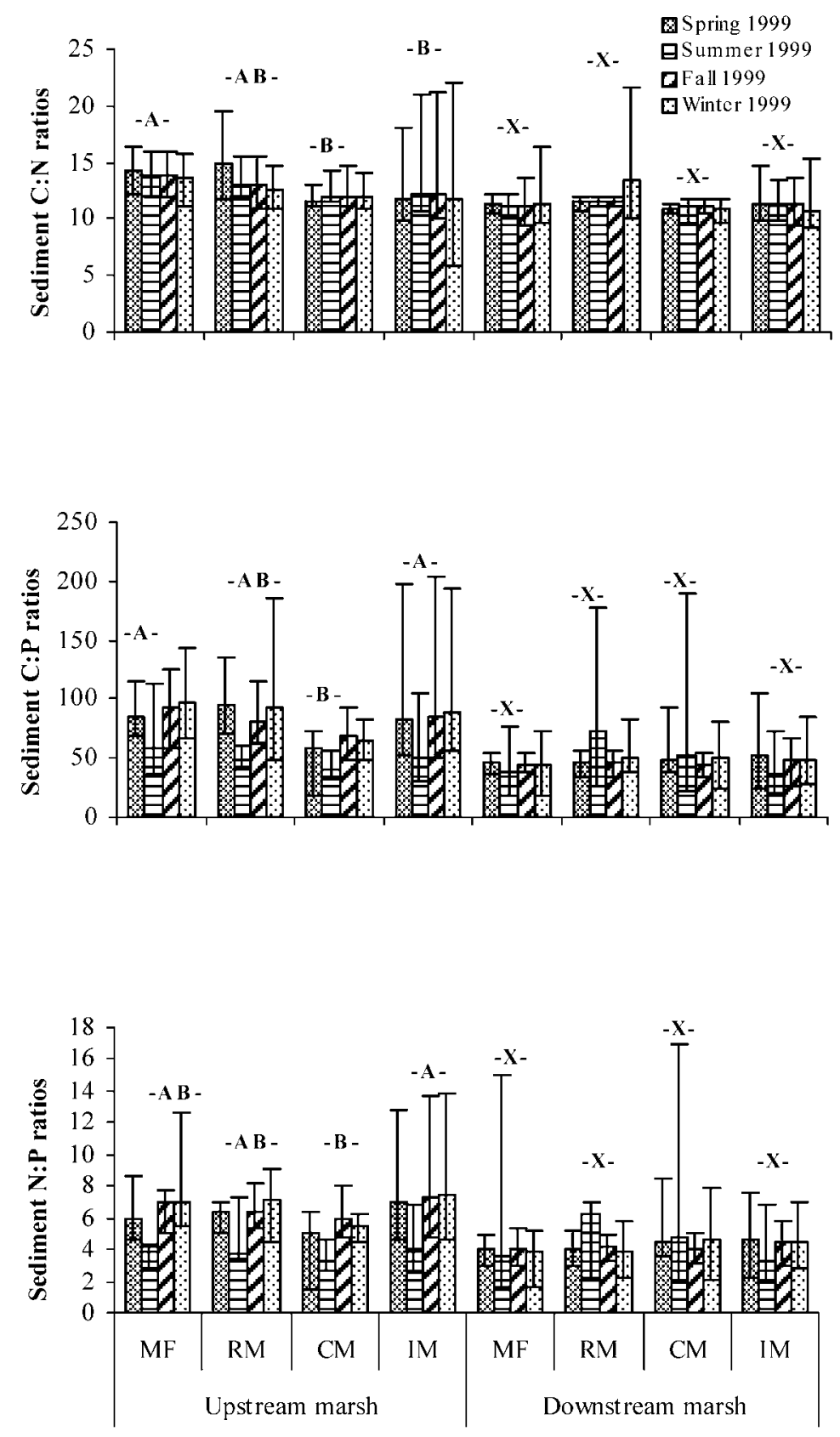

Figure 4. Seasonal sediment C:N, C:P, and N:P ratios, by marsh and location. Bars shows the range of values. Marshes are significantly different at $p<0.05$ when labeled with different letter series $(\mathrm{ABC}>\mathrm{XYZ})$. Locations within marshes are significantly different at $p<0.05$ when labeled with different letters. Summer C:P and N:P ratios were significantly lower than other seasons at the downstream marsh. 

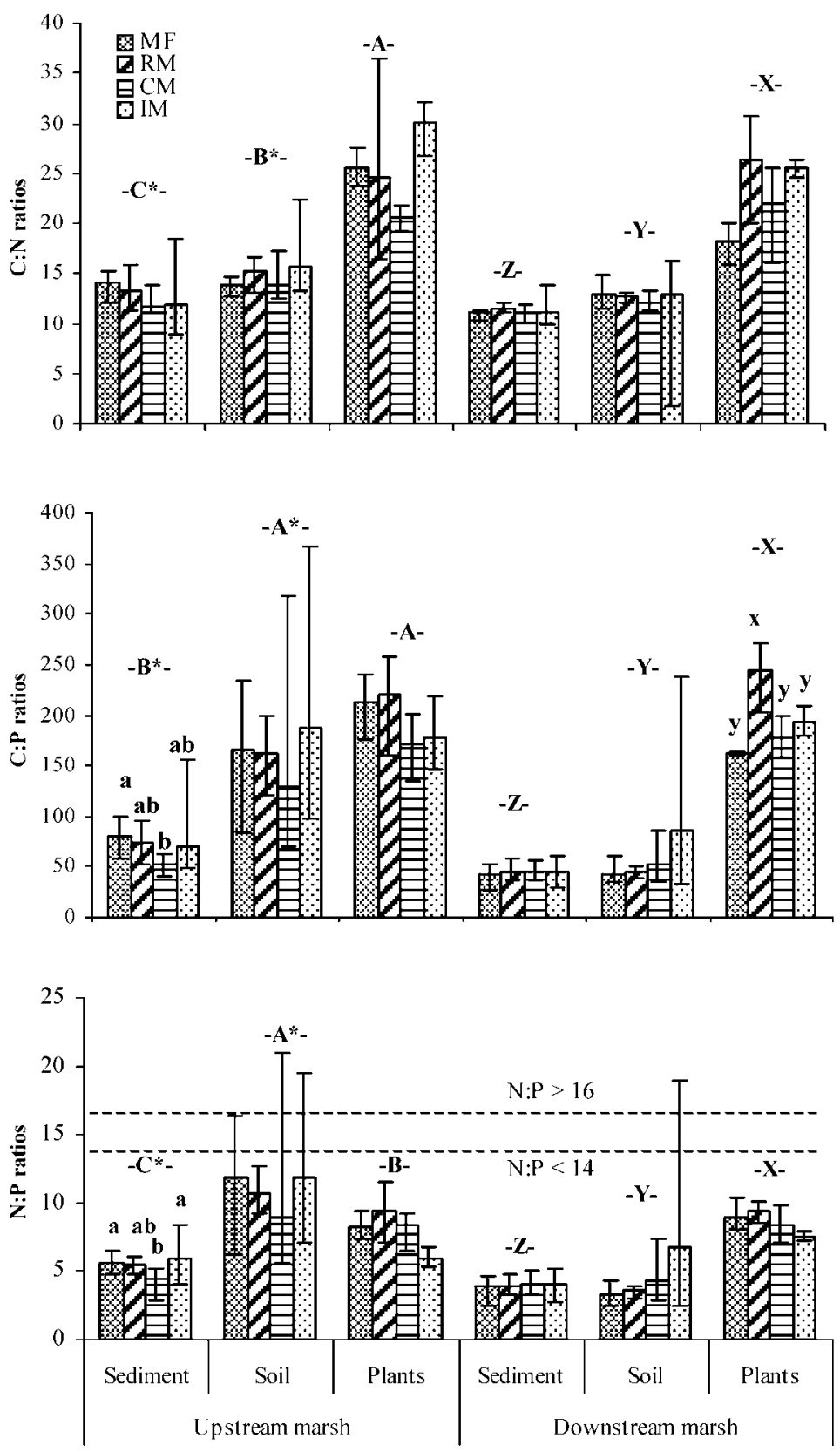

Figure 5. Ecosystem C:N, C:P, and N:P ratios, by marsh, location, and sample type. Bars show the range of values. Marshes are significantly different overall at $p<0.05$ when labeled with different letter series $(\mathrm{ABC}>\mathrm{XYZ}$ ). Sample types and locations within marshes are significantly different at $p<0.05$ when labeled with different letters. Sample types are significantly different between marshes when labeled with an asterisk. 

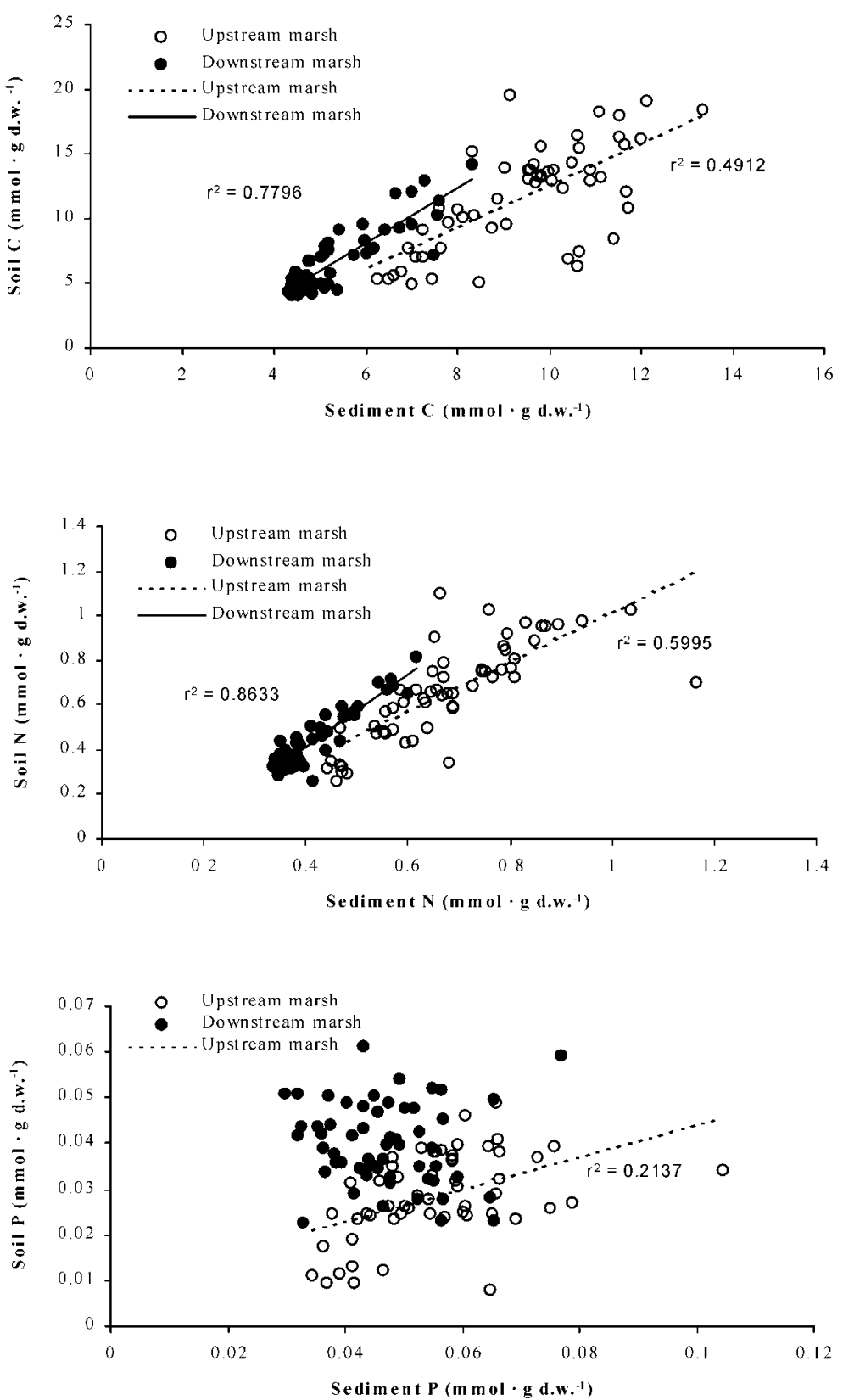

Figure 6. Relationships between sediment and soil concentrations of $\mathrm{C}, \mathrm{N}$, and $\mathrm{P}(\mathrm{mmol} /$ g.d.w.), with marshes shown separately. Linear trendlines and $r^{2}$ values are displayed when significant at $p<0.05$. 
sediments, soil and plant $\mathrm{C}: \mathrm{N}, \mathrm{C}: \mathrm{P}$, and $\mathrm{N}: \mathrm{P}$ ratios were all significantly higher at the upstream marsh. At both sites, $\mathrm{C}: \mathrm{N}$ ratios were higher in above ground plant tissues than in sediments or soils. At the upstream site, C:P ratios were significantly higher in surface soils and above ground plant tissues than in accumulated sediments, while N:P ratios were significantly higher in surface soils than in plant tissues or sediments. Similar to C:N ratios, C:P and N:P ratios at the downstream marsh were significantly higher in plant tissues than in accumulated sediments or surface soils (Figure 5).

Accumulated sediments at the upstream marsh were higher in both $\mathrm{C}$ and $\mathrm{N}$ per unit of soil $\mathrm{C}$ and $\mathrm{N}$, respectively, than accumulated sediments at the downstream marsh (Figure 6). In contrast, while the $\mathrm{P}$ concentrations of accumulated sediments varied over similar ranges in both marshes $(0.03-0.10 \%)$, soil $\mathrm{P}$ concentrations were higher at the downstream marsh (Figure 6).

\section{Phosphorus fractions in accumulated sediments and surface soils}

Differences in sediment accumulation rates between marshes, and between locations within marshes, were reflected in the accumulation rates of sediment $\mathrm{P}$ fractions. Total $\mathrm{P}$ was determined by summing $\mathrm{P}$ fractions, and was consistently lower than total $\mathrm{P}$ determined by digestion, in both accumulated sediments and soils. Annual accumulation rates for total $\mathrm{P}$ ranged from 0.095 to $0.974 \mathrm{~g} \mathrm{~m}^{-2}$ at the upstream marsh, and $0.287-2.826 \mathrm{~g} \mathrm{~m}^{-2}$ at the downstream marsh (Figure 7(a)). Annual accumulation rates of sediment $\mathrm{P}$ fractions were all significantly higher at the downstream marsh. In both marshes, mudflats had significantly higher sediment $P$ fraction accumulation rates than IM locations (Figure 7(b)). At the upstream marsh, spatial variations were significant for four sediment $\mathrm{P}$ fractions $\left(\mathrm{Fe}-\mathrm{P}_{\mathrm{i}}, \mathrm{Al}-\right.$ $\mathrm{P}_{\mathrm{o}}$, Ca-P, and Res-P); at the downstream marsh, spatial variations were significant for all sediment $\mathrm{P}$ fractions except water-soluble $\mathrm{P}_{\mathrm{i}}$, water-soluble $\mathrm{P}_{\mathrm{o}}$, and HA-P (Morse 2002).

With the exception of water-soluble $\mathrm{P}_{\mathrm{o}}$ and HA-P, pool sizes of all soil $\mathrm{P}$ fractions were significantly higher at the downstream marsh, consistent with the higher observed sediment $\mathrm{P}$ accumulation rates (Figure 7(a)). However, there was little spatial variation in the pool sizes of soil $\mathrm{P}$ fractions in either marsh. At the upstream marsh, water-soluble $\mathrm{P}$ was significantly higher in $\mathrm{CM}$ than in other locations; at the downstream marsh, Ca-P was significantly higher in MF and RM than in IM locations (Morse 2002).

Organic $\mathrm{P}$ comprised a significant proportion of total $\mathrm{P}$ in accumulated sediments and surface soils at both marshes. At both sites, organic P represented a larger percentage of total $\mathrm{P}$ in surface soils than in accumulated sediments $-88 \%$ versus $59 \%$ for the upstream marsh and $70 \%$ versus $50 \%$ for the downstream marsh (Figure 8 ). The fractional composition of $\mathrm{P}$ in accumulated sediments was generally similar at both marshes, with $\mathrm{Al}-\mathrm{P}_{\mathrm{o}}$ and $\mathrm{Fe}-\mathrm{P}_{\mathrm{i}}$ comprising $64 \%$ and $53 \%$ of total Pat the upstream and downstream sites, respectively. Sediment HA-P was slightly higher at the upstream marsh (11\% vs. 5\%), and Ca-P was higher at the downstream 

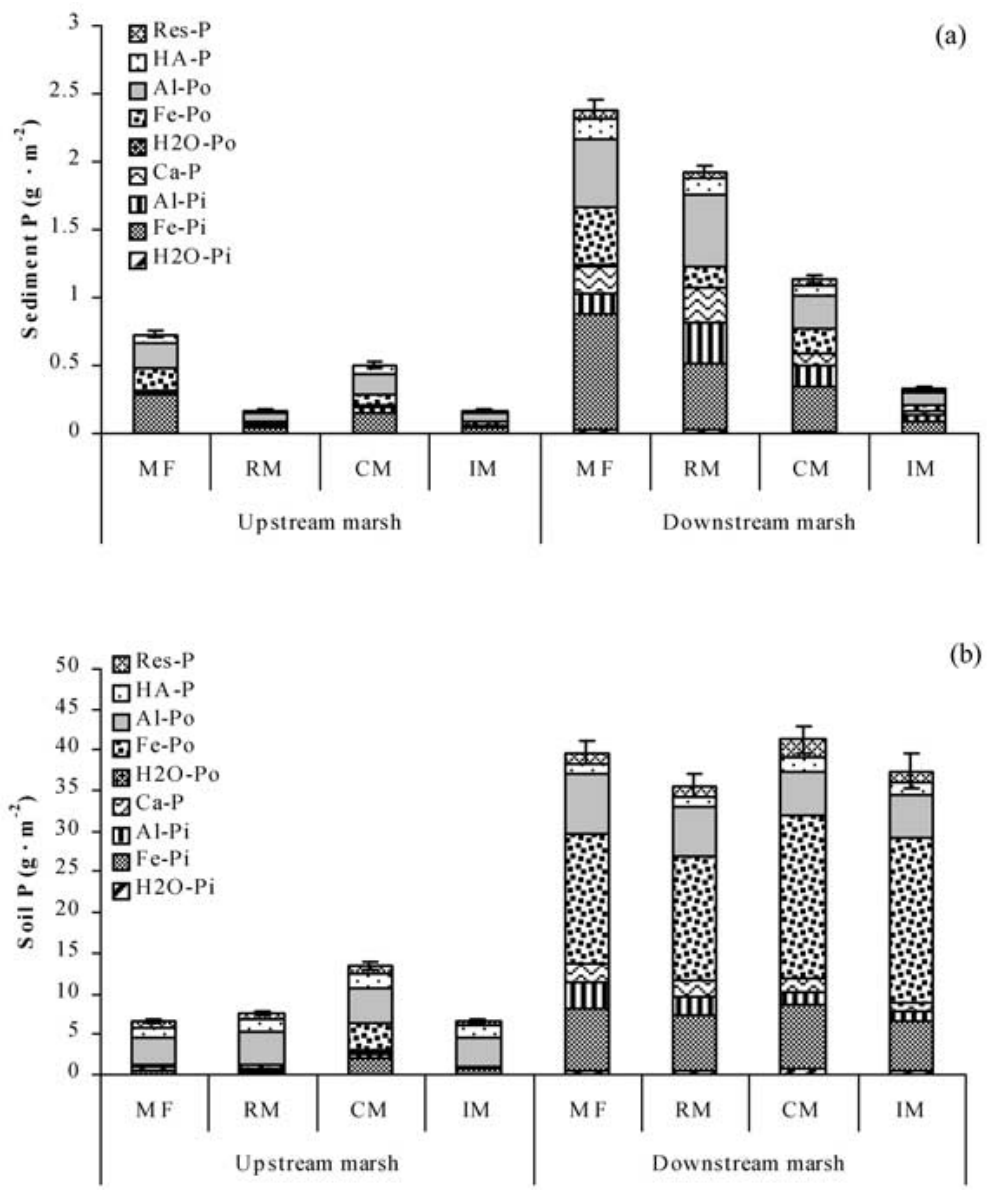

Figure 7. Sediment $\mathrm{P}$ accumulation rates $\left(\mathrm{g} \mathrm{P} \cdot \mathrm{m}^{-2} \cdot \mathrm{yr}^{-1}\right)$ (a) and soil $\mathrm{P}$ pool sizes (b) in fractions from Paludan and Jensen (1995) extraction, by marsh and location. Bars are \pm standard errors over all fractions.

marsh (9\% vs. $2 \%)$. Surface soil P fractions differed significantly between the two sites, however (Figure 8). Aluminum-bound organic P (49\%) was clearly the most important fraction in surface soils at the upstream marsh, followed by HA-P (23\%), Fe- $\mathrm{P}_{\mathrm{i}}(9 \%)$, and Res-P (9\%; Figure 8). Iron-bound organic P, high only in CM locations at the upstream marsh (27\%), represented the most important soil $\mathrm{P}$ fraction at the downstream marsh (40\%) followed by $\mathrm{Fe}-\mathrm{P}_{\mathrm{i}}(20 \%)$ and $\mathrm{Al}-\mathrm{P}_{\mathrm{o}}(20 \%$; Figure 8). The percentage of bioavailable $\mathrm{P}$ in sediments (the sum of organic and inorganic Al-P, Fe-P, and $\mathrm{H}_{2} \mathrm{O}-\mathrm{P}$; Paludan and Morris 1999) was significantly higher at the upstream marsh (85\% upstream vs. $82 \%$ downstream; $p<0.001$; Figure 8). In contrast, bioavailable $\mathrm{P}$ in surface soils at the downstream marsh was significantly higher than at the upstream marsh and accounted for a larger percentage of total P (86\% vs. 66\%; $p<0.089$; Figure 8 ). 


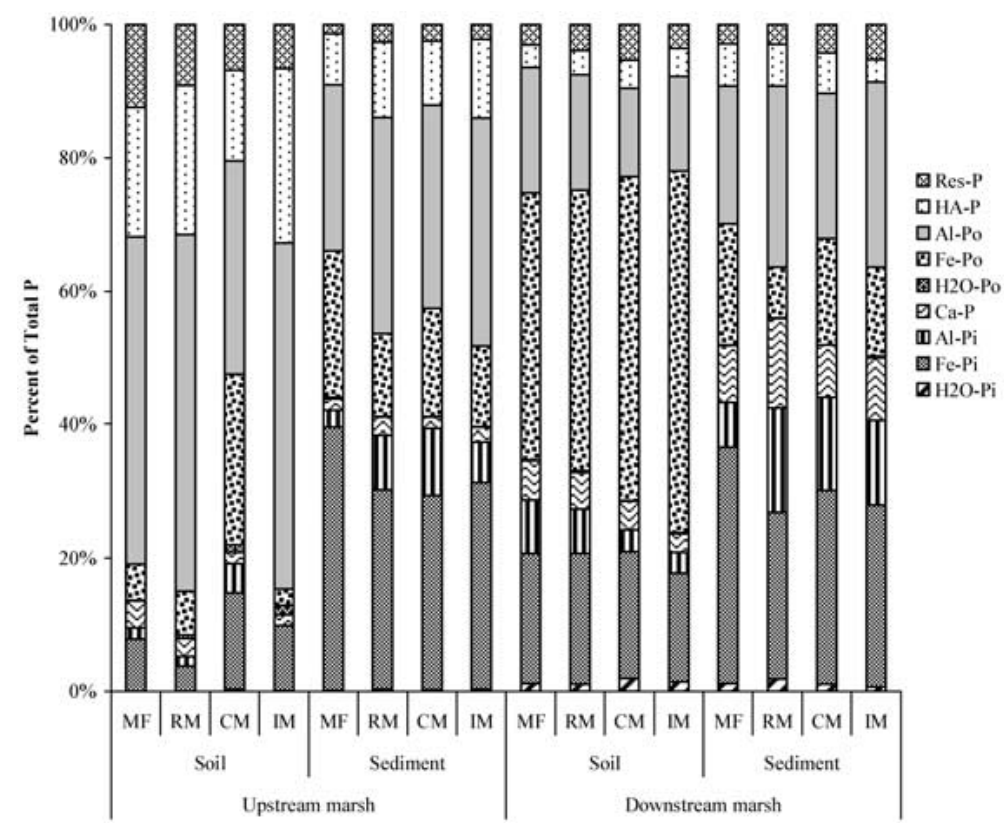

Figure 8. Soil and sediment $\mathrm{P}$ in fractions from Paludan and Jensen (1995) extraction, as a percentage of total $\mathrm{P}$, by marsh and location.

\section{Available and microbial biomass $P$}

Similar trends were observed for available and microbial biomass $\mathrm{P}$ in both accumulated sediments and surface soils (Figure 9). Available (0.5 $\mathrm{M} \mathrm{NaHCO}_{3^{-}}$ extractable) $\mathrm{P}$ was twice as high in sediments $\left(0.39 \pm 0.04 \mathrm{~g} \mathrm{~m}^{-2}\right)$ and over 4 times higher in surface soils $\left(14.6 \pm 2.8 \mathrm{~g} \mathrm{~m}^{-2}\right)$ at the downstream versus the upstream marsh $\left(0.11 \pm 0.02\right.$ and $3.1 \pm 1.0 \mathrm{~g} \mathrm{~m}^{-2}$, respectively; Figure 9). Microbial biomass $\mathrm{P}$ did not differ significantly between marshes in either accumulated sediments or surface soils (Figure 9; Morse 2002). Only available $P_{i}$ differed spatially in either accumulated sediments or surface soils. Available $P_{i}$ was significantly higher in CM versus IM locations at the upstream marsh, and in MF versus IM locations at the downstream marsh (Figure 9; Morse 2002).

\section{Effects of $N$ and/or $P$ fertilization on above ground peak biomass}

Above ground biomass in fertilized plots did not differ significantly from above ground biomass in control plots in either marsh (Figure 10). Above ground 

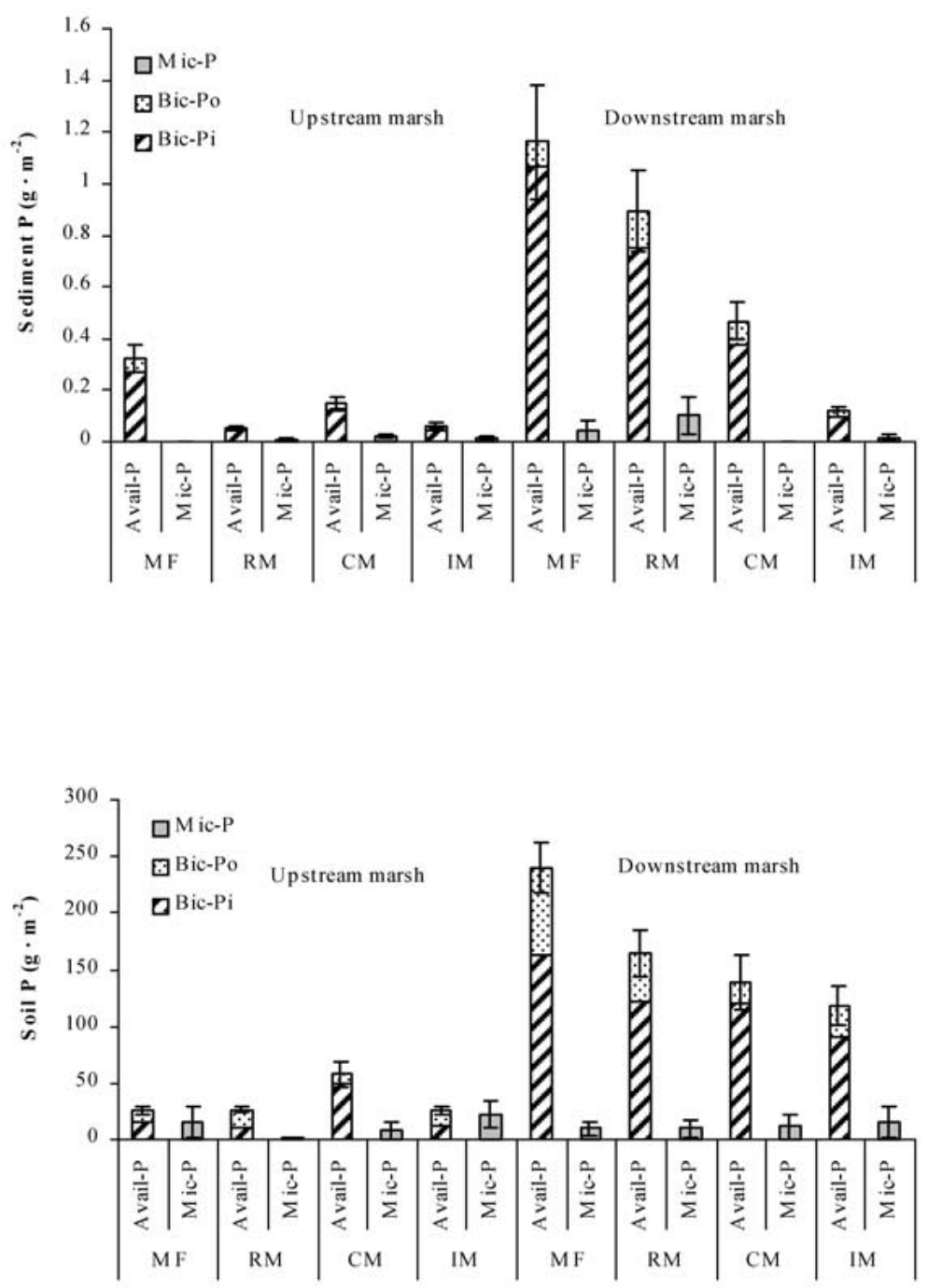

Figure 9. Sediment and soil available $\mathrm{P}$ (Avail-P = Bic-Pi + Bic-Po) and microbial biomass $\mathrm{P}(\mathrm{Mic}-\mathrm{P})$ pool sizes by marsh and location. Bars are \pm standard errors.

biomass did increase with both $\mathrm{N}$ and $\mathrm{P}$ fertilization at the upstream marsh, although not significantly. At the downstream marsh, above ground biomass was lower, although not significantly lower, in plots receiving $\mathrm{P}$ fertilization. Fertilization did not significantly affect soil $\mathrm{N}$ concentrations (Figure 11). Soil P concentrations decreased significantly with $\mathrm{N}$ fertilization at the downstream site, but showed no other significant changes with treatment in either marsh (Figure 11). 


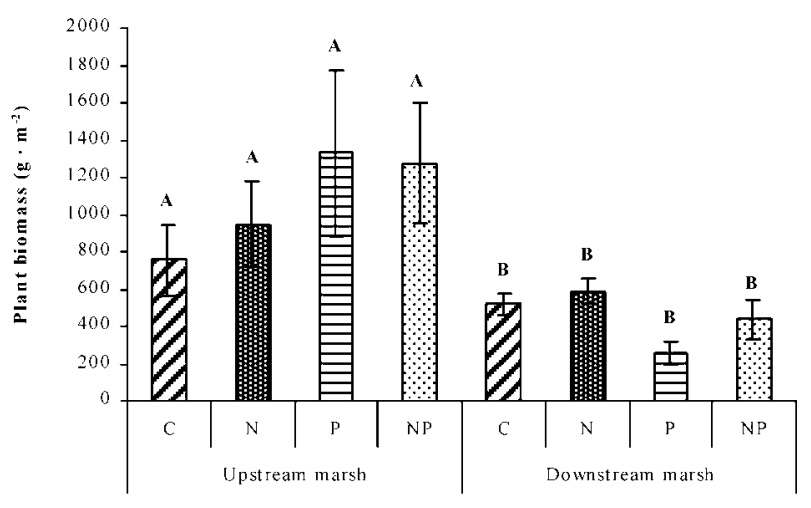

Figure 10. Plant biomass in experimental plots, by marsh and treatment. Bars are \pm standard errors. Marshes are significantly different at $p<0.05$ when labeled with different letter series. Treatments are significantly different from control plots at $p<0.05$ when labeled with different letters.
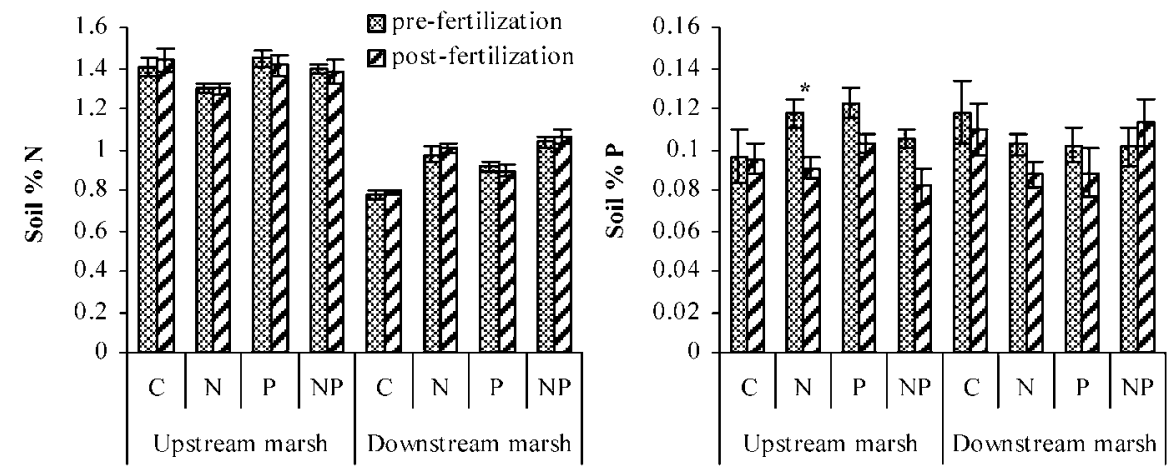

Figure 11. Soil $\mathrm{N}$ and $\mathrm{P}$ concentrations in experimental plots, by marsh and treatment. Bars are \pm standard errors. Soil pairs (pre- vs. post-fertilization) are significantly different at $p<0.05$ when labeled with an asterisk.

\section{Discussion}

Sedimentation processes are critical to our discussion of nutrients in these TFMs because sedimentation is main mechanism for nutrient delivery to TFMs (Odum 1988). Darke and Megonigal (2003) dealt more extensively with sediment dynamics during the same study period in these marshes. They report that sediment deposition rates in both marshes were at the low end of the range reported for similar TFMs in the Chesapeake Bay region. Measured vertical accretion rates were significantly higher at the downstream marsh $\left[1.2 \mathrm{~cm}_{\text {year }}{ }^{-1}\right.$ at the upstream marsh vs. $2.7 \mathrm{~cm} \mathrm{year}^{-1}$ at the downstream marsh; Darke and Megonigal (2003)], and in both marshes, were roughly twice as high as accretion rates calculated using our 
estimates of yearly sediment accumulation and surface soil bulk densities $\left(0.62 \mathrm{~cm} \mathrm{year}^{-1}\right.$ at the upstream marsh vs. $1.70 \mathrm{~cm}$ year $^{-1}$ at the downstream marsh; Table 1, Figure 3). In another mid-Atlantic TFM, contemporary accretion rates have been averaging $0.97 \mathrm{~cm}_{\text {year }}{ }^{-1}$ (Orson et al. 1990). These data suggest that our estimates of sediment, and thus nutrient, inputs to the marshes are reasonable, even though our method of measuring sediment accumulation does not account for local resuspension and redeposition. However, because this study encompassed only 12 months of sediment collection, we cannot provide a measure of year-to-year variability in sediment nutrient delivery to these marshes.

We hypothesized that soil nutrient availability and the $\mathrm{C}, \mathrm{N}$, and $\mathrm{P}$ stoichiometries of surface soils and plant tissues would reflect rates and stoichiometries of $\mathrm{C}$, $\mathrm{N}$, and $\mathrm{P}$ in accumulated sediments. Soil $\mathrm{P}$ availability did appear to be directly related to sediment $\mathrm{P}$ accumulation, with higher soil $\mathrm{P}$ content at the downstream marsh where sediment $\mathrm{P}$ inputs were highest, but the $\mathrm{C}$ and $\mathrm{N}$ stoichiometries of surface soils did not reflect $\mathrm{C}$ and $\mathrm{N}$ inputs in accumulated sediments (Tables 1 and 2; Figure 5). In turn, surface soil $\mathrm{C}, \mathrm{N}$, and $\mathrm{P}$ pool sizes were not reflected in above ground plant biomass $\mathrm{C}, \mathrm{N}$, and $\mathrm{P}$ stoichiometries (Tables 1 and 3; Figure 5).

The upstream marsh received significantly less $\mathrm{P}$ in accumulated sediments, and had smaller soil $\mathrm{P}$ pool sizes and higher sediment and soil $\mathrm{C}: \mathrm{P}$ and $\mathrm{N}: \mathrm{P}$ ratios than the downstream marsh (Tables 1 and 2; Figure 5). In contrast, soil $\mathrm{C}$ and $\mathrm{N}$ pool sizes were similar at both marshes, despite the lower $\mathrm{C}$ and $\mathrm{N}$ accumulation rates in sediments observed at the upstream marsh (Figures 4 and 5). Thus, while sediment $\mathrm{P}$ accumulation appeared to contribute significantly to soil $\mathrm{P}$ availability in these marshes, other processes (e.g., riparian transport, transformation, translocation) are probably more important in controlling $\mathrm{C}$ and $\mathrm{N}$ availability.

In both marshes, organic $\mathrm{P}\left(\mathrm{P}_{\mathrm{o}}\right)$ comprised a larger percentage of total $\mathrm{P}$ in soils than sediments. Organic $\mathrm{P}$ accounted for 88 and $70 \%$ of total soil $\mathrm{P}$, compared to 59 and $49 \%$ of total sediment $\mathrm{P}$, at the upstream and downstream marshes, respectively (Figure 8). The transformation of inorganic $\mathrm{P}$ inputs to organic forms is known to be an important function of riparian wetlands (Whigham et al. 1988; Richardson 1989; Walbridge and Lockaby 1994). The larger percentages of organic P in these marsh soils compared to accumulated sediments, suggests that internal transformation of inorganic sediment $\mathrm{P}$ inputs to organic form may be an important function in these freshwater tidal marshes as well.

The importance of geochemical processes in controlling the cycling and availability of P, as compared to N, in soils is also well documented (Schlesinger 1997; but see Wood et al. 1984; Walbridge et al. 1991). In fresh waters near the salt water mixing zone, the precipitation of $\mathrm{P}$ sorbed to $\mathrm{Fe}$ - and Al-hydroxides and of colloids formed by flocculation of dissolved humic acids with $\mathrm{Fe}^{3+}$ and phosphate (involving carboxylic and phenolic groups on humic acids) are important mechanisms of P removal from the water column (Sholkovitz et al. 1978; Lucotte and d'Anglejan 1988; Lebo 1991; Jones et al. 1993). High proportions of Fe-P (67.5\% of total P) in soils at the downstream marsh suggest that this mechanism also contributes to $\mathrm{P}$ inputs to TFMs. In Chesapeake Bay TFMs, sedimentation and burial of P-rich sediments in accreting zones has also been found to be a significant mechanism of $\mathrm{P}$ 
storage (Correll et al. 1992; Khan and Brush 1994; Boynton et al. 1995). In contrast, the majority of $\mathrm{N}$ in TFM soils is held in organic forms that are resistant to decomposition, while the remaining pool of inorganic $\mathrm{N}$ is small and tightly cycled between microbial and plant biomass pools (Bowden 1987; Mitsch and Gosselink 2000). However, the apparent biogeochemical transformation of $P_{i}$ to $P_{o}$, and the decrease in bioavailable $\mathrm{P}$ from $85 \%$ in sediments to $66 \%$ in soils at the upstream marsh, suggest the additional importance of biological processes to $\mathrm{P}$ cycling in these TFMs (Figure 7; Paludan and Morris 1999).

In contrast to our hypothesis that spatial and seasonal variations in sediment deposition and nutrient availability within marshes would be more significant than differences between marshes, the most obvious differences were found between marshes. We considered a variety of environmental factors that might have contributed to these differences, including surface elevation, marsh age, land use, local geomorphology, and position on the riverine-estuarine gradient. Since mean elevations for all location classes were higher at the downstream marsh (Figure 2), differences in surface elevation do not appear to explain the differences between sites in sediment or $\mathrm{P}$ inputs. We do not have extensive data on the age of the individual marshes, but preliminary results indicate that these TFMs began forming from late Holocene sediments about 4000 y BP (GR Whittacre in preparation).

Darke and Megonigal (2003) discussed some of these variables in their explanation of between-site differences in sedimentation in these two marshes during the same time period. Land use is largely similar upstream of each marsh. Although marsh and mudflat areas increase along the river between the two sites, increasing available sediment sources, this is unlikely to wholly account for the order of magnitude differences in sedimentation observed between sites (Darke and Megonigal 2003). Both marshes occupy similar positions on the river, on inner bends of the meandering channel; a sandy point bar at the upstream marsh is the major distinguishing feature between them. River discharge and flow velocity are related factors that surely differ between the two marshes and may also have a role in determining sediment deposition.

Another likely candidate is the position of the marshes along the riverine-estuarine gradient, specifically the closer proximity of the downstream marsh to the ETM. In estuaries, zones of maximum turbidity tend to migrate with fluctuating freshwater discharge. As reported by Lin and Kuo (2001), in periods of extremely low flows in the Mattaponi River, such as 1997 in their study and likely in 1999 during the present study (USGS 2002), the ETM moved upstream from its average location near West Point, VA, up to $90 \mathrm{~km}$ beyond the mouth of the York River. Our downstream site is located approximately $81 \mathrm{~km}$ from the mouth of the York River, which places the ETM squarely in the vicinity of our sites during Summer 1999. In their analysis of factors controlling sediment dynamics in these sites, Darke and Megonigal (2003) concluded that the closer proximity to the ETM of the downstream site, and the greater availability of sediment sources, were the principal factors governing sediment deposition there. Thus, it appears that variability of discharge, salinity, and other factors within the tidal freshwater zone may cause significant differences in marsh nutrient characteristics over relatively short distances (i.e., $19 \mathrm{~km}$ ). 
Sediment and associated $\mathrm{C}, \mathrm{N}$, and $\mathrm{P}$ accumulation rates were the most striking differences observed between the two marshes (Table 2; Figure 3). Although the marshes did not differ in soil $\mathrm{C}$ and $\mathrm{N}$ pools, or in pools of $\mathrm{C}, \mathrm{N}$, or $\mathrm{P}$ in above ground plant biomass (Tables 1 and 3), soils at the upstream marsh were more organic, and lower in $\mathrm{pH}$, bulk density, and $\mathrm{P}$ availability than at the downstream marsh (Table 1). Soil texture analysis did not reveal statistically significant differences between the marshes, in part due to low sample size and high variability (Table 1). While both marshes had general characteristics and soil nutrients similar to those reported by Odum et al. (1984) for East Coast TFMs, the downstream marsh had some aspects (e.g., $\mathrm{pH}$, vegetation, finer sediments) seen in marshes in the transition between fresh and brackish waters (Paludan and Morris 1999).

In other types of freshwater wetlands (e.g., swamps and riparian forests), productivity has been shown to increase with the higher nutrient availability associated with sediments deposited during seasonal or periodic flooding (Mitsch and Gosselink 2000). In these TFMs, however, higher sediment accumulation at the downstream marsh did not translate to higher productivity (Table 3). The range of peak biomass estimates measured in July 1999 in these TFMs $\left(96.0-775.7 \mathrm{~g} \mathrm{~m}^{-2}\right)$ is lower than the ranges observed by Whigham et al. (1978) (432.0-2311.0 $\mathrm{g} \mathrm{m}^{-2}$ ) and Odum et al. (1984) (1000.0-3500.0 $\mathrm{g} \mathrm{m}^{-2}$ ). The single-harvest method is known to underestimate ANPP (Whigham et al. 1978). However, peak biomass measured during the fertilization experiment (August 2000) was twice as high in the IM zones at the upstream marsh compared to the drought year 1999, but not at the downstream marsh (Table 3; Figure 10). Either tidal flooding does not provide the same subsidy to TFMs as riparian flooding does to other freshwater wetlands, or the periodic influence of salinity and associated high deposition of fine sediments at the downstream marsh suppress ANPP even in non-drought years, despite the nutrient subsidy provided through flooding.

Accumulated sediments at the upstream marsh were higher in $\mathrm{C}$ and $\mathrm{N}$ per unit of soil $\mathrm{C}$ and $\mathrm{N}$ compared to the downstream marsh, suggesting different sources of sediment for the two marshes (Figure 6). Differences in soil P characteristics between the two marshes, such as the prevalence of Al-P and HA-P at the upstream site and of $\mathrm{Ca}-\mathrm{P}$ and $\mathrm{Fe}-\mathrm{P}$ at the downstream site, could be explained by the higher clay content at the downstream marsh (Table 1), and the higher periodic salinity due to its greater proximity to the ETM. Paludan and Morris (1999) found similar decreases in $\% \mathrm{P}_{\mathrm{o}}$ and \% HA-P, and increases in \% Ca-P, in marsh soils along a gradient of increasing salinity. Rates of clay deposition at the downstream site suggest that the ETM may have migrated farther upstream than usual and increased sediment deposition at the downstream marsh during this drought period (Darke and Megonigal 2003). Dominance of riverine influences at the upstream marsh was suggested by larger soil particle size, lower soil $\mathrm{pH}$, and lower soil $\mathrm{P}$ availability (Table 1); episodic but pronounced estuarine influences at the downstream site were suggested by the high clay content, Ca-P in soils and sediments, transitional brackish water plant species (S. cynosuroides; Odum et al. 1984; Silberhorn and Zacherle 1987), and soil classification (Typic Sulfaquent; Three Rivers Soil and Water Conservation District, personal communication). Phosphorus is known to 
sorb to $\mathrm{Fe}$ hydroxides and to associate with humic acids in the presence of $\mathrm{Fe}$ in suspended particulate matter in fresh and brackish waters, although it is increasingly released from $\mathrm{Fe}$ as salinity and $\mathrm{pH}$ increase (Froelich 1988; Lucotte and d'Anglejan 1988; Lebo 1991; Jones et al. 1993; Paludan and Morris 1999; Sundareshwar and Morris 1999).

Spatial and seasonal variations within marshes were often significant, but there were few consistent patterns. When present, spatial variations were most often found between MF and IM locations, which were separated by the greatest lateral distance and differences in elevation (Figure 2). Flood depth and duration in TFMs are tightly linked to surface elevation (Darke and Megonigal 2003), and thus to sediment deposition (Figures 2 and 3). Accumulation of sediments and associated $\mathrm{C}, \mathrm{N}$, and $\mathrm{P}$, was highest in MF locations vs. IM locations in both marshes, yet similar spatial patterns were not observed in soils (Tables 1 and 2). Clearly, C, N, and $\mathrm{P}$ inputs from sediments are reworked and transformed within these marshes, physically by erosional and depositional processes and biologically by plant and microbial activity; thus, spatial patterns of nutrient accumulation in sediments do not translate directly to soil C, N, and P pool sizes within the marshes (Table 1). Sediment and soil $\mathrm{P}$ fractions also showed little spatial variation within marshes (Figures $7 \mathrm{a}$ and $\mathrm{b}$ ). Seasonal differences in sedimentation were more pronounced at the downstream marsh, where sediment, $\mathrm{C}, \mathrm{N}$, and $\mathrm{P}$ accumulation rates were higher during summer compared to other seasons; only sediment $\mathrm{P}$ accumulation was higher during summer at the upstream marsh (Table 2). Increased sediment deposition during summer, and with increasing proximity to the river margin in TFMs, has also been noted by other researchers (e.g., Serodes and Troude 1984; Puckett et al. 1993; Hensel et al. 1998; Pasternack and Brush 1998). In addition, Hatton et al. (1982) found pronounced differences in soil nutrients between nearchannel levees and backmarsh areas.

Above ground biomass followed the same spatial pattern as soil $\mathrm{C}$ and $\mathrm{N}$ pools at the downstream marsh-higher in IM than in MF locations; at the upstream marsh, higher biomass was measured in both CM and IM locations, and appeared to be independent of soil nutrient availability as estimated by soil $\mathrm{N}$ and $\mathrm{P}$ pool sizes, which were highest in CM locations and lowest in IM locations. The interiors of both marshes likely function to retain nutrients, as more $\mathrm{N}$ and $\mathrm{P}$ are sequestered in above ground biomass there, particularly in plants such as $P$. virginica which retranslocate $\mathrm{N}$ and $\mathrm{P}$ into belowground biomass for storage, following the growing season (Klopatek 1978; Simpson et al. 1983; Booth 1989). Stratigraphic records from TFM sediments show that $\mathrm{N}$ and $\mathrm{P}$ storage, through burial of peat and recalcitrant organic compounds, tends to increase from low to high marsh, as sites mature (Khan and Brush 1994).

As we hypothesized, the N:P ratios $<14$ observed in accumulated sediments, surface soils, and above ground plant tissues all suggest that $\mathrm{N}$ limits primary production in these TFMs (Figure 5). Similarities in plant nutrient content and growing season peak biomass in both marshes suggest that soil $\mathrm{P}$ availability probably does not limit plant growth in either marsh (Tables 1 and 3). Lower N:P ratios in sediments and soils, resulting from higher $\mathrm{P}$ inputs in accumulated sedi- 
ments, are consistent with relatively lower $\mathrm{N}$ availability at the downstream marsh (Figure 5). Sediment $\mathrm{P}$ accumulation rates during summer were significantly higher than during other seasons in both marshes; this increase in $\mathrm{P}$ availability during the growing season makes it additionally unlikely that $\mathrm{P}$ limits plant growth in these marshes (Table 2).

Despite these trends, we observed no significant increase in either above ground peak biomass or soil nutrient availability in either marsh following $\mathrm{N}, \mathrm{P}$, or $\mathrm{N}+\mathrm{P}$ additions (Figures 9 and 10). As $\mathrm{N}$ and $\mathrm{P}$ concentrations in above ground plant tissues do not suggest severe nutrient deficiency (van den Driessche 1974), one explanation for the lack of growth response might be that nutrient availability in general does not limit primary production in these marshes, although the lack of an above ground growth response to fertilization does not conclusively demonstrate that a nutrient is not limiting (Chapin et al. 1986). Also, below ground plant response was not quantified. Our method of nutrient delivery-adding nutrients once at the beginning of the growing season, even as resin-coated, slow-release pellets (Worm et al. 2000)-may not have been the best method to ensure that experimental plots received the intended nutrient supply. Some workers have found it necessary to conduct fertilization experiments for several consecutive growing seasons before seeing results (Svengsouk and Mitsch 2001). The lack of growth response could also have been an artifact of the small area $\left(0.0625 \mathrm{~m}^{2}\right)$ sampled in the experimental plots. In the year prior to the experiment, we had not observed a great deal of heterogeneity in the vegetation or soil surface of the IM zones to be fertilized; however, a posteriori analysis of soil nutrients indicated that there was greater variability before fertilization than at the time of harvest (Morse 2002).

Other investigators also have documented difficulties in determining the nature of nutrient limitation in TFMs. Booth (1989), working in VA TFMs along the Pamunkey River, concluded that N was likely to be limiting to Spartina cynosuroides, but that $P$. virginica, with substantial nutrient storage in its rhizome, was less responsive to changes in soil nutrient availability. In a VA TFM on the Chickahominy River, dominated by P. virginica, Chambers and Fourqurean (1991) found it difficult to determine nutrient limitation through the use of $\mathrm{N}: \mathrm{P}$ ratios, porewater nutrients, or plant response to fertilization.

Although generally $<14$, soil N:P ratios in tidal marshes may vary as a function of both soil organic matter content and salinity. Verhoeven et al. (2001) found soil $\mathrm{N}: \mathrm{P}$ ratios $<14$ in a range of TFMs in both the US (Maryland) and Europe (Belgium and The Netherlands), occurring on both mineral and organic soils. In contrast, Bowden (1984) reported N:P ratios ranging from 13 to 28 in the top $20 \mathrm{~cm}$ of highly organic soils in a New England TFM. Hatton et al. (1982) found that in Louisiana tidal fresh and transitional marshes, soils high in OM (20-52\%) had N:P ratios ranging from 16 to 27 in TFMs, while brackish and salt marshes had N:P ratios ranging from 10 to 20. Bedford et al. (1999) also noted a positive relationship between soil $\mathrm{N}: \mathrm{P}$ ratio and $\mathrm{OM}$ content in a wide range of temperate North American wetland soils. Sundareshwar and Morris (1999) observed increases in P availability, and decreases in soil N:P ratios, with increasing salinity in South Carolina marsh and swamp soils. 
Our hypotheses relating to ecosystem nutrient limitation were based upon the critical N:P ratios established by Koerselman and Meuleman (1994) in European wetlands. More recently, these findings were re-examined by Güsewell et al. (2003), who found that plant biomass N:P ratios did not reliably predict how individual plant populations would respond to fertilization, particularly when those populations were limited by $\mathrm{N}$ as opposed to $\mathrm{P}$, and therefore could not be used to predict changes in plant species composition in response to changes in nutrient supply. Güsewell et al. (2003) suggest, however, that N:P ratios are still useful in assessing relative nutrient availability and plant nutrient deficiency, particularly when used comparatively in fertilization experiments. As other researchers have previously found (e.g., Walbridge 1991; Lockaby and Walbridge 1998; Bedford et al. 1999), our results suggest that both plant and particularly soil N:P stoichiometries are useful indices of relative nutrient availability.

We have described the delivery of nutrients via sediments and the current nutrient status in two TFMs in the Chesapeake Bay region, a contribution to the basic knowledge of TFM biogeochemistry. In addition, given the current relatively pristine state of the Mattaponi River and these representative TFMs, our study provides a useful baseline against which to identify future changes in ecosystem structure and function that could result from a variety of factors. Estuarine and riverine sedimentation processes, and thus nutrient inputs to TFMs and nutrient processes within the marshes, are sensitive to changes in land use and hydrological regime, and may also be affected by regional trends and events resulting from global change and rising sea levels.

\section{Acknowledgements}

The authors thank many people who assisted in the field and laboratory: D. Berliner, A. Darke, R. DuBois, K. Fitzgerald, D. Foullon, S. Hall, E. Kiehl, W. Kornicker, J.-W. Kwon, J. Martin, M. Moore, J. Orr, A. Peacock, K. Redden, B. Roberts, and L. Roberts. A.K. Darke and D. Hogan were very generous with their assistance in the laboratory. J. Miller was most helpful with statistical analyses. R. McBride, G. Taylor, and three anonymous reviewers provided comments that improved this manuscript. We are grateful to the landowners, including the gracious Mattaponi Tribe, who permitted us to access their properties. This research was funded in part by The Nature Conservancy through a grant to JPM and in part through a Fellowship to JLM from the Environmental Science and Policy Department at George Mason University.

\section{References}

Barko J.W., Gunnison D. and Carpenter S.R. 1991. Sediment interactions with submersed macrophyte growth and community dynamics. Aquat. Bot. 41: 41-65.

Bedford B.L., Walbridge M.R. and Aldous A. 1999. Patterns in nutrient availability and plant diversity of temperate North American wetlands. Ecology 80 (7): 2151-2169. 
Booth Jr. P.M. 1989. Nitrogen and Phosphorus Cycling Strategies in Peltandra virginica and Spartina cynosuroides. The College of William and Mary, Williamsburg, VA.

Bouyoucos G.J. 1962. Hydrometer method improved for making particle size analysis of soils. Agron. J. 54: 464-465.

Bowden W.B. 1984. Nitrogen and phosphorus in the sediments of a tidal freshwater marsh in Massachusetts. Estuaries 7 (2): 108-118.

Bowden W.B. 1987. The biogeochemistry of nitrogen in freshwater wetlands. Biogeochemistry 4: 313-348.

Boynton W.R., Garber J.H., Summers R. and Kemp W.M. 1995. Inputs, transformations, and transport of nitrogen and phosphorus in Chesapeake Bay and selected tributaries. Estuaries 18 (1B): 285-314.

Bran and Luebbe Inc. 1989. Technicon Autoanalyzer II Methods. Technicon Instruments Corporation, Buffalo Grove, IL.

Brush G.S. 1984. Patterns of recent sediment accumulation in Chesapeake Bay tributaries. Chem. Geol. 44: 227-242.

Cahoon D.R., Reed D.J. and Day Jr. J.W. 1995. Estimating shallow subsidence in microtidal salt marshes of the southeastern United States: Kaye and Barghoorn revisited. Marine Geol. 128: 1-9.

Callaway J.C., Nyman J.A. and DeLaune R.D. 1996. Sediment accretion in coastal wetlands: a review and a simulation model of processes. Curr. Top. Wetl. Biogeochem. 2: 2-23.

Chambers R.M. and Fourqurean J.W. 1991. Alternative criteria for assessing nutrient limitation of a wetland macrophyte (Peltandra virginica (L.) Kunth). Aquat. Bot. 40: 305-320.

Chapin F.S., Vitousek P.M. and Van Cleve K. 1986. The nature of nutrient limitation in plant communities. Am. Nat. 127 (1): 48-58.

Chesapeake Bay Program 2001. Bay Atlas. http://rock.chesapeakebay.net. Accessed 16 April 2001.

Correll D.L., Jordan T.E. and Weller D.E. 1992. Nutrient flux in a landscape: effects of coastal landuse and terrestrial community mosaic on nutrient transport to coastal waters. Estuaries 15 (4): 431-442.

Cowardin L.M., Carter V., Golet F.C. and Laroe E.T. 1979. Classification of wetlands and deepwater habitats of the United States. FWS/OBS-79/31. US Fish and Wildlife Service, Washington, DC

Daoust R.J. and Childers D.L. 1999. Controls on emergent macrophyte composition, abundance, and productivity in freshwater Everglades wetland communities. Wetlands 19 (1): 262-275.

Darke A.K. and Megonigal J.P. 2003. Control of sediment deposition rates in two mid-Atlantic coast tidal freshwater wetlands. Estuarine, Coastal Shelf Sci. 57 (1-2): 259-272.

DiTommaso A. and Aarssen L.W. 1989. Resource manipulations in natural vegetation: a review. Vegetatio 84: 9-29.

Dyer K.R. 1994. Estuarine sediment transport and deposition. In: Pye K. (ed) Sediment Transport and Depositional Processes. Blackwell Scientific Publications, Boston, MA, pp. 193-218.

Froelich P.N. 1988. Kinetic control of dissolved phosphate in natural rivers and estuaries: a primer on the phosphate buffer mechanism. Limnol. Oceanogr. 33 (4): 649-668.

Gee G.W. and Bauder J.W. 1986. Particle size analysis. In: Klute S. (ed) Methods of Soil Analysis. American Society of Agronomy, Madison, WI, pp. 383-411.

Godfrey R.K. and Wooten J.W. 1979. Aquatic and Wetland Plants of Southeastern United States: Monocotyledons. The University of Georgia Press, Athens, GA.

Godfrey R.K. and Wooten J.W. 1981. Aquatic and Wetland Plants of Southeastern United States: Dicotyledons. University of Georgia Press, Athens, GA.

Güsewell S., Koerselman W. and Verhoeven J.T.A. 1998. The N:P ratio and the nutrient limitation of wetland plants. Bull. Geobot. Inst. ETH 64: 77-90.

Güsewell S., Koerselman W. and Verhoeven J.T.A. 2003. Biomass N:P ratios as indicators of nutrient limitation for plant populations in wetlands. Ecol. Appl. 13 (2): 372-384.

Hatton R.S., Patrick Jr. W.H. and DeLaune R.D. 1982. Sedimentation, nutrient accumulation, and early diagenesis in Louisiana Barataria Basin coastal marshes. In: Kennedy V.S. (ed) Estuarine Comparisons. Academic Press, New York, NY, pp. 255-267.

Hatton R.S., DeLaune R.D. and Patrick Jr. W.H. 1983. Sedimentation, accretion, and subsidence in marshes of Barataria Basin, Louisiana. Limnol. Oceanogr. 28: (3) 494-502.

Hedley M.J. and Stewart J.W.B. 1982. Method to measure microbial phosphate in soils. Soil Biol. Biochem. 14: 377-385. 
Hensel P.F., Day J.W., Pont D. and Day J.N. 1998. Short-term sedimentation dynamics in the Rhône River Delta, France: the importance of riverine pulsing. Estuaries 21 (1): 52-65.

Jones R.I., Shaw P.J. and De Haan H. 1993. Effects of dissolved humic substances on the speciation of iron and phosphate at different pH and ionic strength. Environ. Sci. Technol. 27 (6): 1052-1059.

Kastler J.A. and Wiberg P.L. 1996. Sedimentation and boundary changes of Virginia salt marshes. Estuar. Coast. Shelf S. 42: 683-700.

Khan H. and Brush G.S. 1994. Nutrient and metal accumulation in a freshwater tidal marsh. Estuaries 17 (2): $345-360$

Kiehl K., Esselink P. and Bakker J.P. 1997. Nutrient limitation and plant species composition in temperate salt marshes. Oecologia 111: 325-330.

Klopatek J.M. 1978. Nutrient dynamics of riverine marshes. In: Good R.E., Whigham D.F. and Simpson R.L. (ed) Freshwater Wetlands: Ecological Processes and Management Potential. Academic Press, New York, NY, pp. 195-216.

Koerselman W. and Meuleman A.F.M. 1994. The vegetation N:P ratio: a new tool to detect the nature of nutrient limitation. J. Appl. Ecol. 33: 1441-1450.

Koroleff F. 1983. Determination of nutrients. In: Grasshoff K., Ehrhardt M. and Kremling K. (ed) Methods of Seawater Analysis. Verlag Chemie, Weinheim, pp. 125-139.

Lebo M.E. 1991. Particle-bound phosphorus along an urbanized coastal plain estuary. Marine Chem. 34: 225-246.

Leonard L.A. 1997. Controls of sediment transport and deposition in an incised mainland marsh basin. Wetlands 17 (2): 263-274.

Lin J. and Kuo A.K. 2001. Secondary turbidity maximum in a partially mixed microtidal estuary. Estuaries 25 (5): 707-720.

Lockaby B.G. and Walbridge M.R. 1998. Biogeochemistry. In: Messina M.G. and Conner W.H. (ed) Southern Forested Wetlands Ecology and Management. Lewis Publishers, Washington, DC, pp. 149-172.

Lucotte M. and d'Anglejan B. 1988. Processes controlling phosphate adsorption by iron hydroxides in estuaries. Chem. Geol. 67: 75-83.

McManus J. 1998. Temporal and spatial variations in estuarine sedimentation. Estuaries 21 (4A): $622-634$.

Mitsch W.J. and Gosselink J.G. 2000. Wetlands. John Wiley \& Sons, Inc., New York, NY.

Moore D.R.J., Keddy P.A., Gaudet C.L. and Wisheu I.C. 1989. Conservation of wetlands: do infertile wetlands deserve a higher priority? Biol. Conserv. 47: 203-217.

Morris J.T. 1991. Effects of nitrogen loading on wetland ecosystems with particular reference to atmospheric deposition. Ann. Rev. Ecol. Syst. 22: 257-279.

Morris J.T. and Bradley P.M. 1999. Effects of nutrient loading on the carbon balance of coastal wetland sediments. Limnol. Oceanogr. 44 (3): 699-702.

Morse J.L. 2002. Sediment accumulation and nutrient availability in two tidal freshwater marshes along the Mattaponi River, Virginia. George Mason University, Fairfax, VA.

Murphy J. and Riley J. 1962. A modified single solution method for the determination of phosphate in natural waters. Anal. Chim. Acta 27: 31-36.

National Oceanic and Atmospheric Administration 1997. NOAA Estuarine Eutrophication Survey. Office of Resources Conservation and Assessment, Silver Spring, MD.

National Wetlands Inventory 2001. Wetlands Interactive Mapper. http://wetlands2.nwi.fws.gov. Accessed 16 April 2001

Nelson D.W. and Sommers L.E. 1996. Total carbon, organic carbon, and organic matter. In: Bigham J.M. (ed) Methods of Soil Analysis: Part 3 - Chemical Methods. Soil Science Society of America Madison, WI, pp. 961-1010.

Odum W.E. 1988. Comparative ecology of tidal freshwater and salt marshes. Ann. Rev. Ecol. Syst. 19: $147-176$.

Odum W.E., Smith T.J., Hoover J.K. and McIvor C.C. 1984. The ecology of tidal freshwater marshes of the United States East Coast: a community profile. FWS/OBS-83/17 US Fish and Wildlife Service, Washington, DC. 
Orson R.A., Simpson R.L. and Good R.E. 1990. Rates of sediment accumulation in a tidal freshwater marsh. J. Sedimentol. Petrol. 60: 859-869.

Orson R.A., Simpson R.L. and Good R.E. 1992. The paleoecological development of a late Holocene, tidal freshwater marsh of the upper Delaware River estuary. Estuaries 15: 130-146.

Paludan C. and Jensen H.S. 1995. Sequential extraction of phosphorus in freshwater wetland and lake sediment: significance of humic acids. Wetlands 15 (4): 365-373.

Paludan C. and Morris J.T. 1999. Distribution and speciation of phosphorus along a salinity gradient in intertidal marsh sediments. Biogeochemistry 45: 197-221.

Pasternack G.B. and Brush G.S. 1998. Sedimentation cycles in a river-mouth tidal freshwater marsh. Estuaries 21 (3): 407-415.

Patrick Jr. W.H. and DeLaune R.D. 1976. Nitrogen and phosphorus utilization by Spartina alterniflora in a salt marsh in Barataria Bay, Louisiana. Estuar. Coast. Marine Sci. 4: 59-64.

Perry J.E. and Atkinson R.B. 1997. Plant diversity along a salinity gradient of four marshes on the York and Pamunkey Rivers in Virginia. Castanea 62 (2): 112-118.

Peterjohn W.T. and Correll D.L. 1984. Nutrient dynamics in an agricultural watershed: observations on the role of a riparian forest. Ecology 65 (5): 1466-1475.

Puckett L.J., Woodside M.D., Libby B. and Schening M.R. 1993. Sinks for trace metals, nutrients, and sediments in wetlands of the Chickahominy River near Richmond, Virginia. Wetlands 13 (2): $105-114$.

Reddy K.R., Kadlec R.H., Flaig E. and Gale P.M. 1999. Phosphorus retention in streams and wetlands: a review. Crit. Rev. Environ. Sci. Technol. 29 (1): 83-146.

Richardson C.J. 1989. Freshwater Wetlands: Transformers, Filters, or Sinks? In: Sharitz R.R. and Gibbons J.W. (ed) Freshwater Wetlands and Wildlife. US DOE Office of Scientific and Technical Information, Oak Ridge, TN, pp. 25-46.

SAS Institute 1999. SAS Procedures Guide, Version 8 for Windows. SAS Institute, Inc., Cary, NC.

Schlesinger W.H. 1997. Biogeochemistry: an analysis of global change. Academic Press, New York, NY.

Serodes J.B. and Troude J.P. 1984. Sedimentation cycle of a freshwater tidal flat in the St. Lawrence Estuary. Estuaries 7 (2): 119-127.

Shaver G.R. and Melillo J.M. 1984. Nutrient budgets of marsh plants: efficiency concepts and relation to availability. Ecology 65 (5): 1491-1510.

Sholkovitz E.R., Boyle E.A. and Price N.B. 1978. The removal of dissolved humic acid and iron during estuarine mixing. Earth Planet. Sci. Lett. 40: 130-136.

Silberhorn G.M. and Zacherle A.W. 1987. King William and Town of West Point tidal marsh inventory. Special Report No. 289 in Applied Marine Science and Ocean Engineering. Virginia Institute of Marine Science, Gloucester Point, VA.

Simpson R.L., Good R.E., Walker R. and Frasco B.R. 1983. The role of Delaware River freshwater tidal wetlands in the retention of nutrients and heavy metals. J. Environ. Quality 12 (1): 41-48.

Sprague L.A., Langland M.J., Yochum S.E., Edwards R.E., Blomquist J.D., Shenk G.W. and Preston S.D. 2000. Factors Affecting Nutrient Trends in Major Rivers of the Chesapeake Bay Watershed. US Geological Survey, Richmond, VA

Stevenson J.C., Kearney M.S. and Pendleton E.C. 1985. Sedimentation and erosion in a Chesapeake Bay brackish marsh system. Marine Geol. 67: 213-235.

Sundareshwar P.V. and Morris J.T. 1999. Phosphorus sorption characteristics of intertidal marsh sediments along an estuarine salinity gradient. Limnol. Oceanogr. 44 (7): 1693-1701.

Sundareshwar P.V., Morris J.T., Hoepfler E.K. and Fornwalt B. 2003. Phosphorus limitation of coastal ecosystem processes. Science 299: 563-565.

Svengsouk L.J. and Mitsch W.J. 2001. Dynamics of mixtures of Typha latifolia and Schoenoplectus tabernaemontani in nutrient-enrichment wetland experiments. Am. Midland Nat. 145: 309-324.

United States Geological Survey 2002. http://water.usgs.gov. Accessed 3 June 2003.

Valiela I., Teal J.M. and Sass W. 1973. Nutrient retention in salt marsh plots experimentally fertilized with sewage sludge. Estuar. Coast. Marine Sci. 1: 261-269.

van den Driessche R. 1974. Prediction of mineral nutrient status of trees by foliar analysis. Bot. Rev. 40: 347-394. 
van Wijnen H.J. and Bakker J.P. 1999. Nitrogen and phosphorus limitation in a coastal barrier salt marsh: the implications for vegetation succession. J. Ecol. 87: 265-272.

Verhoeven J.T.A., Koerselman W. and Meuleman A.F.M. 1996. Nitrogen- or phosphorus-limited growth in herbaceous, wet vegetation: relations with atmospheric inputs and management regimes. Trends Ecol. Evol. 11 (12): 494-497.

Verhoeven J.T.A., Whigham D.F., van Logtestijn R. and O'Neill J. 2001. A comparative study of nitrogen and phosphorus cycling in tidal and non-tidal riverine wetlands. Wetlands 21 (2): 210-222.

Vitousek P.M., Aber J.D., Howarth R.W., Likens G.E., Matson P.A., Schindler D.W., Schlesinger W.H. and Tilman D.G. 1997. Human alteration of the global nitrogen cycle: sources and consequences. Ecol. Appl. 7 (3): 737-750.

Walbridge M.R. 1991. Phosphorus availability in acid organic soils of the lower North Carolina coastal plain. Ecology 72 (6): 2083-2100.

Walbridge M.R. and Lockaby B.G. 1994. Effects of forest management on biogeochemical functions in southern forested wetlands. Wetlands 14 (1): 10-17.

Walbridge M.R. and Struthers J.P. 1993. Phosphorus retention in non-tidal palustrine forested wetlands of the Mid-Atlantic region. Wetlands 13: 84-94.

Whigham D.F., Chitterling C. and Palmer B. 1988. Impacts of freshwater wetlands on water quality: a landscape perspective. Environ. Manage. 12 (5): 663-671.

Walbridge M.R., Richardson C.J. and Swank W.T. 1991. Vertical distribution of biological and geochemical phosphorus subcycles in two southern Appalachian forest soils. Biogeochemistry 13: 61-85.

Whigham D.F., McCormick J., Good R.E. and Simpson R.L. 1978. Biomass and primary production in freshwater tidal wetlands of the Middle Atlantic Coast. In: Good R.E., Whigham D.F. and Simpson R.L. (ed) Freshwater Wetlands: Ecological Processes and Management Potential. Academic Press, New York, NY, pp. 3-20.

Whittecar G.R., Megonigal J.P. and Darke A.K. in preparation. Geomorphic evolution of fresh-water tidal wetlands, Mattaponi River, Virginia. For: Wetlands.

Wolaver T.G., Zieman J.C., Wetzel R. and Webb K.L. 1983. Tidal exchange of nitrogen and phosphorus between a mesohaline vegetated marsh and the surrounding estuary in the lower Chesapeake Bay. Estuar. Coast. Shelf S. 16: 321-332.

Wood T.E., Bormann F.H. and Voigt G.K. 1984. Phosphorus cycling in a northern hardwood forest: biological and chemical control. Science 223: 391-393.

Worm B., Reusch T.B.H. and Lotze H.K. 2000. In situ nutrient enrichment: methods for marine benthic ecology. Int. Rev. Hydrobiol. 85 (2-3): 359-375 